\title{
Functional Tissue Engineering of Ligament and Tendon Injuries
}

DOI:

10.1016/B978-0-12-381422-7.10054-9

Link to publication record in Manchester Research Explorer

\section{Citation for published version (APA):}

Cartmell, S., Woo, S. L. Y., Almarza, A. J., Karaoglu, S., Liang, R., \& Fisher, M. B. (2011). Functional Tissue Engineering of Ligament and Tendon Injuries. In Principles of Regenerative Medicine/Princ. of Regenerative Med. (pp. 997-1021). Elsevier BV. https://doi.org/10.1016/B978-0-12-381422-7.10054-9

\section{Published in:}

Principles of Regenerative Medicine|Princ. of Regenerative Med.

\section{Citing this paper}

Please note that where the full-text provided on Manchester Research Explorer is the Author Accepted Manuscript or Proof version this may differ from the final Published version. If citing, it is advised that you check and use the publisher's definitive version.

\section{General rights}

Copyright and moral rights for the publications made accessible in the Research Explorer are retained by the authors and/or other copyright owners and it is a condition of accessing publications that users recognise and abide by the legal requirements associated with these rights.

\section{Takedown policy}

If you believe that this document breaches copyright please refer to the University of Manchester's Takedown Procedures [http://man.ac.uk/04Y6Bo] or contact uml.scholarlycommunications@manchester.ac.uk providing relevant details, so we can investigate your claim.

\section{OPEN ACCESS}




\title{
Chapter Number
}

\section{Tissue Engineering of Ligaments}

\author{
Sarah Rathbone and Sarah Cartmell \\ School of Materials, Materials Science Centre, The University of Manchester \\ United Kingdom
}

\section{Introduction}

The main function of a ligament is to connect one bone to another bone across a joint, keeping them aligned to prevent abnormal motions and dislocations. The typical magnitude of force a ligament may experience during day-to-day activities varies. For example the anterior cruciate ligament of the knee can be exposed to daily tensile forces ranging between $67 \mathrm{~N}$ for ascending stairs to $630 \mathrm{~N}$ for jogging (Vunjak-Novakovic, Altman et al. 2004), whereas large loads, exceeding $1800 \mathrm{~N}$, can cause rupturing. Depending upon anatomical location and the extent of vascularisation, the ligament may or may not be capable of selfhealing after a rupture.

Some of the most frequently ruptured ligaments occur in the knee joint, often through sporting activities such as skiing, football and basketball and the number of injuries are increasing each year (Cooper, Lu et al. 2005). Ninety percent of knee ligament injuries involve the anterior cruciate ligament (ACL) and medial collateral ligament (MCL) (Woo, Abramowitch et al. 2006). The MCL can self-heal, but the ACL cannot due to poor vascularisation. Because of this, alternative methods such as regenerative medicine have focused heavily upon the ACL with the aim of producing a fully functional tissue in vitro.

Figures indicate that approximately 250,000 people are diagnosed with ACL injuries each year in the USA (Doroski and Brink 2007), and approximately 150,000 need to undergo surgical treatment, known as an ACL reconstruction (Cooper, Lu et al. 2005). If the rupture is not treated it can cause loss of function of the associated joint which can then lead to early development of osteoarthritis (Cooper and Bailey 2006; Gentleman, Livesay et al. 2006).

The current gold standard procedure for an ACL reconstruction is surgical autografting. This involves using part of the patients own patellar tendon, hamstring or quadriceps to replace the ruptured ACL (Beasley, Weiland et al. 2005). However, these techniques cause donor site morbidity (Goulet and Germain 1997; Van Eijk, Saris et al. 2004; Cooper and Bailey 2006; Hairfield-Stein, England et al. 2007) which is associated with pain and a recovery period for the donor tissue site (Cooper, Lu et al. 2005; Hairfield-Stein, England et al. 2007). Generally $75-90 \%$ of patients have good or excellent long term success rates from these current grafting techniques (regarding functional stability and symptomatic relief upon return to normal activities) but unfortunately a substantial number of patients exist who have unsatisfactory results which could be attributed to graft failure (Vergis and Gillquist 1995). Some of these patients continue to endure pain, suffer from loss of motion secondary to the operative procedure and continue with recurrent instability (Vergis and Gillquist 1995), while others suffer from degenerative joint disease such as arthritis or 
experience re-injury (Hairfield-Stein, England et al. 2007). Alternatively, allografts can be used where the donor tendon is taken from a cadaver, but the disadvantages associated with this include donor scarcity, the risk of the recipient contracting a disease from the donor, or tissue rejection (Ahmed, Collins et al. 2004; Vunjak-Novakovic, Altman et al. 2004). Prosthetic replacements (synthetic grafts) have previously been used, but these have shown to be inadequate due to wear and degeneration (Mascarenhas and MacDonald 2008). It is evident that surgical ACL reconstructions have limitations and do not always give completely satisfactory long-term results in a high proportion of patients, which consequently affects their quality of life (Vergis and Gillquist 1995; Lanza, Langer et al. 2007). Because of this dilemma, regenerative medicine could be an option, where in vitro tissue engineering of ligaments can offer a solution to the problems associated with the current surgical methods (Van Eijk, Saris et al. 2004; Hairfield-Stein, England et al. 2007). Tissue engineered ligaments could provide better performance in the long run by improved biocompatibility, integration into host tissue and the ability to remodel their own extracellular matrix (Nesic, Whiteside et al. 2006).

Tissue engineering is a method which combines knowledge from material science, engineering, molecular biology and medicine (Nesic, Whiteside et al. 2006). The basic procedure normally involves using scaffolds to act as structural supports for cell growth and maturation in-vitro, where a stimulus (chemical or mechanical) may also be applied to promote the formation of a functional tissue. This concept was originally developed to repair skin and cartilage, but is now being considered as a possible option to produce neoligament tissue. To date, many different types of material have been investigated as potentially suitable scaffolds for ligament tissue engineering, focusing upon their biocompatibility, degradability, surface properties for cell attachment and overall mechanical properties. These include polymers (such as polyurethane, polylactic acid, polyglycolic acid, polycaprolactone, polyhydroxyalkanoates and alginates), silk fibroin, glasses, hydrogels and biological materials such as de-cellularised tissues.

There has been much research into the application of chemical stimulus upon cell culture in vitro. It is well documented that specific growth and differentiation factors can trigger various cellular responses such as cell differentiation, cell division and matrix remodelling (Evans 1999), making them useful in tissue engineering to influence cell behaviour. Some of the most commonly studied growth factors include transforming growth factor beta-1 (TGF- 31 ), basic fibroblast growth factor (bFGF) and epidermal growth factor (EGF). Bioreactors also have applications in tissue engineering, where they can be used to optimise the cell culturing conditions; for example they can improve the mass transfer of nutrients to cells in a 3D scaffold (perfusion), improve cell seeding onto a scaffold (rotation), or provide a mechanical stimulus (in tension or compression) to influence cell behaviour. For ligament tissue engineering, the bioreactor is normally used to apply tensile straining forces within physiological ranges to promote differentiation and extracellular matrix (ECM) synthesis. From the literature, the mechanical loading regimes investigated have varied from $1-10 \%$ strain, $0.01-1 \mathrm{~Hz}$ frequency, from $1 / 2$ hour - 24 hours/day over a period ranging from 1 day to six weeks. Achieving the optimal culturing conditions for a ligament tissue engineered construct can be complex, where small changes can have large affects upon cell behaviour and their final product. This chapter will review in detail the different biomaterials, loading regimes and growth factors that have been currently investigated for this purpose. 


\section{Anatomy of the ligament}

\subsection{Structure and function of a ligament}

A ligament is a capsule of connective tissue made of fibres joining one bone to another across a joint where they help to guide joint motions and prevent abnormal displacement of bones relative to each other (Einhorn, O'Keefe et al. 2007). They are very strong compared to other connective tissues, such as skin, because of the high tensile loads they need to withstand (Einhorn, O'Keefe et al. 2007). Although there are several hundred ligaments in the body, many of the examples given have focused upon the ACL because it is the most frequently injured knee ligament. Figure 1 indicates where the main knee ligaments are located around and within the knee joint.

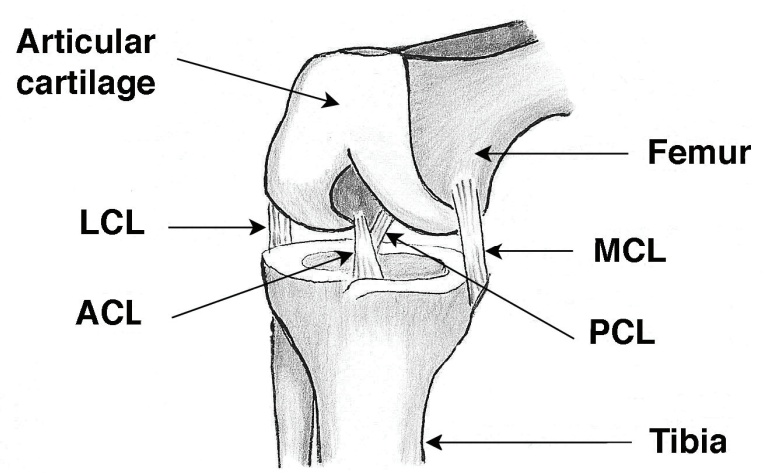

Fig. 1. The diagram illustrates where the fours main knee ligaments are located; the anterior cruciate ligament (ACL), the posterior cruciate ligament (PCL), the medial collateral ligament (MCL), and the lateral collateral ligament (LCL)

There are three main types of connective tissue within the human body, connective tissue proper (loose and dense regular connective tissue), fluid connective tissue (transports substances in blood) and supporting connective tissue (cartilage and bone). Skeletal ligament is a dense regular connective tissue, which is comprised of fibroblasts (connective tissue cells), and extracellular matrix (proteins and water making up the connective tissue). The periodical change in direction of collagen fibres gives the connective tissue a distinct undulating pattern. The fibroblasts (located within in the ECM) are responsible for producing the ECM components to maintain and repair the connective tissue. After an injury, these cells become mobile, migrating to the wounded tissue to increase the synthesis of specific proteins to aid tissue repair (Rogers 1983; Alberts, Johnson et al. 2000). The ECM is composed of two main classes of macromolecules; polysaccharide chains of glycosaminoglycans (which have adhesion functions and attract water), and fibrous proteins such as collagen, elastin and reticular fibres which give structural support to the tissue (Alberts, Johnson et al. 2000). The ground substance of the ECM is a hydrophilic water-like gel containing the polysaccharides and fibrous proteins, allowing diffusion of waste products and nutrients between the tissue cells and capillaries (Hansen, Masouros et al. 2006).

Ligament connective tissue is classed as dense regular tissue because the closely packed collagen fibres are aligned in an ordered regular, way, giving tensile strength and support to 
the tissue. The basic structure of collagen is very similar in all collagen types, where its formation starts with the synthesis of polypeptide chains on the ribosome which are composed mainly of glycine, hydroxylysine and hydroxyproline repeats (Carpenter and Hankenson 2004). Inside the cell, three polypeptide a-chains coil together into a right-hand twist to make a triple helix (super helix) forming the procollagen molecule which then becomes exocytosed from the cell. The procollagen molecules polymerize in the extracellular space firstly by aggregating together into a microfibrils, then aggregating into fibrils, where finally, the fibres become stabilized by covalent cross-links which form within and between the tropocollagen molecules (Alberts, Johnson et al. 2000). It is this extensive cross-linking, particularly in collagen I, which gives the collagen fibrils their stability and great tensile strength, which in turn makes the tissue very strong so that the ligament can resist deformation from stretching forces (Doroski, Brink et al. 2007). Collagen type I, III and V are all structural components of ligament fibrils (Posthemus, September et al. 2009), where type I and III provide tensile strength and type V regulates fibre assembly and diameter (September, Schwellnus et al. 2007). Collagen type $X$ is present where the ligament integrates into the bone. Tenascin-c, another type of protein found in ligament ECM, regulates the tissues response to mechanical loading (September, Schwellnus et al. 2007). The individual collagen fibrils are randomly orientated, but as they aggregate into fibres they gain a more parallel orientation with the longitudinal axis of the ligament, giving the tissue a crimping pattern (wavy appearance) (Goulet, Germain et al. 1997).

\subsection{Bone attachment}

Ligaments attach to the bone surfaces as an aggregation of collagen fibre bundles (Ellenbecker 2000), either by direct insertion, or both direct and indirect insertion. The ACL inserts into the bone by direct insertion, the most common ligament insertion type, where its collagenous fibres attach directly to the bone tissue. The collagenous fibres blend into the fibrocartilaginous layer, interweave through the fibrocartilage zone, through the mineralized fibrocartilage zone, then enter the bone (Beasley, Weiland et al. 2005; Woo, Abramowitch et al. 2006). The calcified collagenous fibres which anchor the ligament firmly to the bone are known as Sharpey's fibres (Einhorn, O'Keefe et al. 2007). The medial collateral ligament (MCL), which is also a knee ligament, is inserted into the bone by both direct and indirect insertion, where the superficial fibres (near to the surface) merge with the periosteum (the connective tissue surrounding the bone), while other fibres penetrate the bone deeper and attach to the bone directly at acute angles (Woo, Abramowitch et al. 2006).

\subsection{Characteristic components of ligament tissue}

It is the variation in ratio between collagen types and other ECM components which gives each ligament type its diversity and characteristic mechanical behaviour (Woo, Abramowitch et al. 2006). Due to the absence of specific markers, ligaments can only be distinguished from other ligaments and other tissue types (eg tendon) by structural, molecular and mechanical properties. Although there is no single specific marker in the ligament, tenscin-c has been considered to be a marker due to its characteristically high amounts in the ligament (Doroski, Brink et al. 2007), where the presence of collagen types I and III, tenomodulin, biglycan, decorin, elastin and fibronectin are also characteristic of ligament tissue (Vunjak-Novakovic, Altman et al. 2004; Chen, Huang et al. 2008). The total amounts and specific ratios of the ECM components, ground substance and cells are 
characteristic properties unique for each type of connective tissue which relate to its anatomical location and function (Vunjak-Novakovic, Altman et al. 2004). Connective tissue types can be differentiated by the presence and total quantities of collagen, tenascin-c, elastin, fibronectin, decorin, biglycan, ratios of collagen types, crimping pattern and collagen fibril diameter. Table 1 lists the main components of a typical ligament as a percentage of their wet weights, whereas those in table 2 are the dry weights of the main collagen types and ratio of collagen type I : III which are unique to the ACL, as reported by various authors.

\begin{tabular}{|l|c|c|c|c|c|c|c|}
$\begin{array}{c}\text { Tissue } \\
\text { type (wet } \\
\text { weight) }\end{array}$ & $\begin{array}{c}\text { Collagen } \\
\text { type I } \\
(\%)\end{array}$ & $\begin{array}{c}\text { Other } \\
\text { collagens } \\
\text { such as } \\
\text { type III, } \\
\text { V, VI (\%) }\end{array}$ & $\begin{array}{c}\text { Elastin } \\
(\mathbf{\%})\end{array}$ & $\begin{array}{c}\text { Fibronectin } \\
\text { and other } \\
\text { glycoproteins } \\
(\%)\end{array}$ & $\begin{array}{c}\text { Proteoglycans } \\
(\%)\end{array}$ & $\begin{array}{c}\text { Water } \\
(\%)\end{array}$ & Author \\
\hline $\begin{array}{l}\text { Ligament } \\
\text { (general) }\end{array}$ & 20 & $3-5$ & $1-2$ & $1-2$ & $<1$ & 70 & $\begin{array}{l}\text { (Einhorn, } \\
\text { O'Keefe } \\
\text { et al. }\end{array}$ \\
\hline
\end{tabular}

Table 1. The biochemical constituents of wet ligament tissue

\begin{tabular}{|l|l|l|l|l|l|}
$\begin{array}{c}\text { Tissue type } \\
\text { (dry } \\
\text { weight) }\end{array}$ & $\begin{array}{c}\text { Collagen } \\
\text { type I (\%) }\end{array}$ & $\begin{array}{c}\text { Collagen } \\
\text { type III (\%) }\end{array}$ & $\begin{array}{c}\text { Collagen } \\
\text { type V (\%) }\end{array}$ & $\begin{array}{c}\text { Ratio of collagen } \\
\text { I : III }\end{array}$ & \multicolumn{1}{c|}{ Author } \\
\hline ACL & $70-80$ & $8-10$ & $10-12$ & $9: 1$ & $\begin{array}{l}\text { (Woo, } \\
\text { Abramowitch et al. }\end{array}$ \\
& & & & $\begin{array}{l}\text { 2006; Doroski, } \\
\text { Brink et al. 2007) }\end{array}$ \\
\hline
\end{tabular}

Table 2. The collagen content of the ACL in dry tissue

\section{Cell adherence}

It is essential for fibroblasts to attach to a substrate and spread out to enable them to grow, proliferate, mature and produce functional tissue. In order for these cells to adhere to their substrate, ECM adhesion proteins such as fibronectin, vitronectin or collagen are required to adsorb to the substrate first, where the cells will then subsequently adhere to the adhesion proteins. Fibronectin can exist in two major forms; (1) soluble plasma fibronectin, a constituent of plasma, and (2) insoluble cellular fibronectin, a component of the ECM (Pankov and Yamada 2002). Cellular fibronectin can be expressed by different cell types including fibroblasts (Pankov and Yamada 2002), where it is found in ligaments and other connective tissues. Studies have found it be up-regulated during ligament formation in embryogenesis where it guides the migrating cells (Laurencin and Freeman 2005).

Integrin-mediated binding enables the cell to become connected to its surroundings by linking the interior of the cell to the ECM proteins (outside the cell). The contact made with the ECM can generate intercellular signals which can affect gene expression, morphology, cell survival (Johansson, Svineng et al. 1997), control cell adherence, cell migration, 
cytoskeletal organization (Sechler, Corbett et al. 1997) regulate growth, proliferation, differentiation, and subsequently affect development or maintenance of the ligament tissue (Alberts, Johnson et al. 2000; Vunjak-Novakovic, Altman et al. 2004). Two known intracellular pathways involved upon integrin-fibronectin binding are the Ras-MAPK (Rasmitogen activated protein kinase) and the FAK (focal adhesion kinase) pathways.

Fibronectin mediated cell adhesion studies have been conducted by various researchers as a technique for improving cell attachment in vitro. Research has shown that cell retention of rat MSC's on fibronectin-coated surfaces was improved (Dennis and Caplan 1993), whilst other studies indicate that it increases the adhesive strength of cells, suggesting it occurred due to the increased number of bonds between fibroblasts and fibronectin-coated glass slides (Athanassiou and Deligianni 2001).

\section{Response of fibroblasts to mechanical stimulus}

\subsection{Mechanical transduction}

Mechanical forces play a major role in the formation and architecture of native tissues in vivo, but also help maintain healthy tissue (homeostasis) in adult tissue. During daily activities, human body tissues are subjected to mechanical forces of various magnitudes, depending upon the activity and posture during these movements. The ACL has been shown to withstand forces of up to $1730 \mathrm{~N}$ in people aged 16-26 years, but much less in people aged 48-86 years, with a mean average of approximately $734 \mathrm{~N}$ (Noyes and Grood 1976). However, the forces which can be tolerated become significantly reduced when they are perpendicular to the bone insertion sites (Einhorn, O'Keefe et al. 2007). The externally applied forces can alter the cells structure, mechanical properties, behaviour, and function (Miyazaki, Hasegawa et al. 2000) which are required for tissue homeostasis (Fulton 1984; Altman, Lu et al. 2002). Tissue homeostasis occurs through ECM remodelling (reorganization) which involves ECM degradation by apoptosis (programmed cell death) and the formation of new tissue by cell proliferation (multiplication). An equilibrium between proliferation and apoptosis is essential during ligament growth, healing, tissue homeostasis and adaptation to exercise (Chuen, Chuk et al. 2004).

The cells are believed to sense mechanical forces either through their cell surface integrin receptors or through ion channels in the cell membrane, and respond accordingly. These external forces can alter the cell structure, its mechanical properties, behaviour, and function (Miyazaki, Hasegawa et al. 2000), where, for example they may increase or decrease ECM production, or regulate proliferate and differentiate. Transducing (converting) external physical forces into cellular signals across the membrane is known as mechanical transduction (Ingber 1999). Although the mechanisms of transduction are not well understood, many investigations have been carried out upon integrin receptors and the cell cytoskeleton that support the theory that the cell senses external mechanical forces from the ECM via the integrin receptors (subsequently causing deformation and reorganisation of the cell cytoskeleton) (Pertigliano, McAllister et al. 2006) and activates specific cellular pathways.

\subsubsection{Cytoskeletal tension}

Upon cell-substrate binding via the integrin receptors, this exerts a force upon the cell cytoskeleton, which generates an intracellular tension. In effect, this links the cell membrane to the nucleus which influences gene expression, by relaying signals from the plasma 
membrane to the nucleus (Matyas, Edwards et al. 1994). The cytoskeleton is composed of a network of protein filaments within the cytoplasm, which maintains cell shape, giving it structure and support, and allowing the cell to bear stress without splitting (Alberts, Johnson et al. 2000). The cytoskeleton has a number of other functions including connecting each fibroblast to other cells and to the substrate, generating tension within the cell to produce stress fibres, and also assisting the cell in locomotion (Fulton 1984). There are three proteins in the cytoskeletal network, actin, tubulin and vimentin, which assemble to form the three main structural filaments of the network system (actin filaments, microtubules, intermediate filaments respectively) (Portner, Bagel-Heyer et al. 2005). Both actin and the intermediate filaments are involved in connecting the fibroblasts' internal structure to other cells and to the ECM. When the fibroblast encounters a suitable substrate, it extends its projections (filopodia), which then attach to the substrate allowing the rest of the cell to adhere. This generates a small tension, where the cell subsequently spreads (Fulton 1984; Alberts, Johnson et al. 2000), promoting formation of stress fibres within the cell. This enables the cell to withstand the tension generated from the cell-ECM contact and make connections with the nucleus to modulate cell behaviour. The effects include activating specific genes (Fulton 1984; Altman, Lu et al. 2002) and generating key proteins (including degrading enzymes and ECM components) to remodel the ECM for promoting new tissue formation (Vunjak-Novakovic, Altman et al. 2004; Portner, Bagel-Heyer et al. 2005).

\subsubsection{Intracellular cell signalling}

The most widely accepted mechanism for mechanical transduction is that involving intracellular signalling pathways. Once the cell binds its substrate, the integrin receptors act as mechanoreceptors, receiving then relaying mechanical signals from the ECM through the cell (as biochemical signals) to the nucleus via intracellular pathways. This can either promote gene expression, regulate growth, proliferation or differentiation, subsequently affecting development or maintenance of the connective tissue (Alberts, Johnson et al. 2000; Vunjak-Novakovic, Altman et al. 2004). The most studied intracellular pathway is the Rasmitogen-activated protein kinase (Ras-MAPK) pathway, which is considered to be the one which acts as a general, but unspecific signal transducer, converting the signal from the applied mechanical stress and relaying it through the cell interior (Chiquet, Sarasa-Renedo et al. 2003). The Ras-MAPK pathway becomes activated once the receptor receives an extracellular mechanical signal. Briefly, the received signal causes a kinase on the receptor to become activated which then activates a GTP-binding protein (Ras protein). The Ras protein causes downstream phosphorylations by activating the first MAP kinase (Raf) in the chain to phosphorylate the next MAP kinase (Mek), which phoshporylates and activates the next MAP kinase (Erk), which subsequently activates other proteins. Eventually the signal reaches the gene regulatory proteins in the nucleus which interact with transcription factors and promoters to regulate gene expression and protein activity (Alberts, Johnson et al. 2000).

\subsubsection{Ion channels}

Besides mechanical transduction via integrin receptors, external forces (stress) can also be conveyed into the cell through stretch-induced ion channels which open and close in response to cell membrane deformation (Matyas, Edwards et al. 1994). Ion channels are cation specific channels located in the cell plasma membrane, which allows rapid diffusion of the ions down their electro-chemical gradients across the lipid bilayer. The channels are 
gated, only opening briefly to allow specific cations (such as calcium, sodium or potassium) to pass through, and then close again. The channel gates open in response to several types of specific stimulus, one those being mechanical stress which operates mechanically-gated channels (Alberts, Johnson et al. 2000), subsequently affecting the cell behaviour. Cyclic stretching has been reported to stimulate $\mathrm{Ca}^{2+}$ influx into osteoblasts, and it is thought that mechanical stretch-induced $\mathrm{Ca}^{2+}$ signal transmission may involve the actin filaments (Wang 2006).

\section{Injuries sustained and healing potential}

Ligaments in skeletally mature people are very strong and stiff at high loads, however, there can be some variation in the mechanical properties of each ligament type depending upon the individuals' gender and age. Strength and stiffness of the ACL has been found to significantly reduce as age increases in adults (Noyes and Grood 1976) and can be significantly lower in adult females compared to their male counterparts (Chandrashekar, Mansouri et al. 2006). Ligaments reach their maximum strength when the loading forces are aligned with the ligament fibres and aligned with the direction of bone insertion, becoming three times as strong as when the force acts perpendicular to the bone insertion sites (Einhorn, O'Keefe et al. 2007). They rupture when the load (externally applied force) becomes too excessive to withstand and the collagen fibres tear apart. The ACL, for example, normally ruptures in the mid-substance (middle region) when the knee joint experiences too much force, but it can also tear at the bone insertion sites. The position of the tibia relative to the femur can increase the magnitude of the stress placed onto the knee joint. The stress becomes greatest when the tibia is fully extended and internally rotated simultaneously, increasing the tension upon specific fibre bundles which are trying to resist deformation and abnormal motion. A rupture of the mid-substance occurs when the crosslinks between the collagen fibrils slip allowing the tropocollagen helix to over-stretch, allowing the tissue to tear (Laurencin and Freeman 2005).

Generally, the blood supply to ligaments is sparse when compared to other tissue types (such as the skin), affecting their healing potential (Einhorn, O'Keefe et al. 2007) which can be limited further by anatomical location, age and gender. The healing capacity of the mature ACL is very low due to its anatomical location. It is encapsulated within the knee joint (intrasynovial), being surrounded by the lubricating synovial fluid, and is poorly vascularised (Amiel, Frank et al. 1984; Ahmed, Collins et al. 2004; Cooper, Lu et al. 2005). As a result it cannot self repair (Cooper, Lu et al. 2005; Lu, Cooper et al. 2005), therefore medical treatment is necessary. There is no direct blood supply from the fibrocartilage zone of the bone to the ACL, so the ACL relies mainly upon diffusion of nutrients and waste through the joint fluid from and to the blood vessels of the surrounding synovial tissue respectively (Beasley, Weiland et al. 2005). The surrounding synovial tissue is vascularized by the medial genicular artery, and the lateral inferior genicular artery, forming a vascular plexus (network of vessels) around the knee. It is the small vessels from the plexus which supply the ligament with the essential nutrients by diffusion (Zantop, Patterson et al. 2005). It possible that a few of these small blood vessels may actually penetrate the ACL and directly supply it with nutrients (Arnoczky 1983). As a result of poor vascularization to the midsubstance, the ACL has a low healing capacity and can not self repair (Carpenter and Hankenson 2004). In contrast to the ACL, the MCL which is extrasynovial can self heal 
spontaneously because it has a greater vascularisation and receives more blood (Carpenter and Hankenson 2004).

After injury, those ligaments which are well vascularized have three stages of healing; inflammation, cellular proliferation and migration, ECM repair and finally ECM remodelling (Laurencin and Freeman 2005). Generally, these stages promote fibroblast proliferation. Fibroblasts and macrophages then migrate to the injured site and granulation tissue forms (stroma). GAG, elastin and collagen are synthesised to form new ECM, and finally the ECM is remodelled, where it initially forms into a disordered tissue but later becomes more organized (Alberts, Johnson et al. 2000; Laurencin and Freeman 2005). With avascular, or poorly vascularised ligaments, this process is not carried out, or only in a limited way, which prevents them from self-healing spontaneously and surgery may be needed to repair them. With the case of the ACL, if left untreated, this could eventually cause osteoarthritis in the knee because the ACL has failed to maintain correct bone alignment and control normal motion across the knee joint (Foster, Butcher et al. 2005; Utukuri, Somayaji et al. 2006).

\section{Surgical treatment}

After rupture, the ligament is normally repaired by surgery, which can be by suturing or grafting. Based upon clinical investigations, surgical grafting has become the gold standard for ligament repair (Einhorn, O'Keefe et al. 2007). In the case of the ACL, a surgical reconstruction is performed which is the only method shown to at least partially restore function, helping to improve the patient's quality of life. This method involves implanting a graft to replace the damaged ligament.

Three main types of grafts can be used; autografts, allografts or synthetic grafts. The current gold standard procedure for reconstructing an ACL is autografting, which involves using a ligament or tendon from another part of the patient's body and using it to replace the damaged ACL. This can be a section from the patients patellar tendon (joining knee cap to tibia) or the hamstring tendon (joining calf muscle to bone in heal) (Beasley, Weiland et al. 2005). Patellar tendon is often used because its strength and mechanical properties are similar to or exceed that of normal native ACL (Fenwick, Hazleman et al. 2002). The central third of the patellar tendon is removed with a piece of knee cap (bone plug) attached to one end, and a section of the tibia attached at the other end (Beasley, Weiland et al. 2005). The damaged ACL is removed, a bone tunnel (channel) is drilled out from the femur and tibia, and the graft is threaded through and screwed into leg bones. This reconstruction operation takes approximately $2 \frac{1}{2}$ hours. Allografting involves using a ligament or tendon from a different human donor, normally a cadaver (corpse). The procedure is the same as autografting, and may give the same results, but disadvantages include donor scarcity, the risk of the recipient contracting a disease from the donor, or tissue rejection (VunjakNovakovic, Altman et al. 2004). Clinical outcomes in the short term can be good, with $80 \%$ success rate in restoring knee stability (Einhorn, O'Keefe et al. 2007). Unfortunately, both autografting and allografting can be unsatisfactory methods for long term performance in some patients, where they suffer from instability (Woo, Abramowitch et al. 2006) due to mechanical failure, fatigue or creeping, (gradual stretching of the tissue under constant load). This occurs due to a slight mismatch in mechanical properties between the graft and native ligament tissue, where the injury may then recur at a later date ( $\mathrm{Lu}$, Cooper et al. 2005). It has been suggested that even two years after the implantation the tendon graft 
remains structurally and mechanically different to normal native ligament and never actually becomes "ligamentised" (Fenwick, Hazleman et al. 2002). Another disadvantage of autografting is donor site morbidity which can cause pain, swelling, local nerve damage, scarring, stiffness weakness or infection (Einhorn, O'Keefe et al. 2007). Synthetic grafts have also been used such as carbon, the Gortex prosthesis, the Stryker-Dacon ligament, the LeedsKeio artificial ligament, LARS ligament and Kennedy ligament augmentation devices, but creeping, fatigue and limited integration between host tissue and the graft have occurred several years after implantation (Ahmed, Collins et al. 2004; Cooper, Lu et al. 2005). The advantages and disadvantages of the current grafting methods are summarized in table 3 .

\begin{tabular}{|c|c|c|c|}
\hline & Autograft & Allograft & Synthetic graft \\
\hline Advantages & $\begin{array}{l}\text { No rejection. } \\
\text { No disease } \\
\text { transmission. } \\
\text { No donor scarcity. }\end{array}$ & $\begin{array}{l}\text { No donor site } \\
\text { morbidity. }\end{array}$ & $\begin{array}{l}\text { No donor site morbidity. } \\
\text { No tissue disease } \\
\text { transmission. } \\
\text { No donor scarcity. }\end{array}$ \\
\hline Disadvantages & $\begin{array}{l}\text { Donor site morbidity. } \\
\text { Patellar fracture. } \\
\text { Quadriceps weakness. } \\
\text { Limited bone } \\
\text { integration. } \\
\text { Mismatch in different } \\
\text { tissue properties, } \\
\text { causing mechanical } \\
\text { failure, creeping, } \\
\text { fatigue. } \\
\text { Recurring injury. }\end{array}$ & $\begin{array}{l}\text { Donor scarcity. } \\
\text { Limited bone } \\
\text { integration. } \\
\text { Tissue rejection. } \\
\text { Mismatch in different } \\
\text { tissue properties, } \\
\text { causing mechanical } \\
\text { failure, creeping, } \\
\text { fatigue. } \\
\text { Recurring injury. }\end{array}$ & $\begin{array}{l}\text { Limited bone integration } \\
\text { (weak graft-host tissue } \\
\text { interface). } \\
\text { Mismatch in different } \\
\text { tissue properties causing } \\
\text { mechanical failure. } \\
\text { Creeping (stretching \& } \\
\text { loosening). } \\
\text { Poor long-term } \\
\text { instability. Fatigue. } \\
\text { Recurring injury. }\end{array}$ \\
\hline
\end{tabular}

Table 3. The advantages and disadvantages of three types of graft

\section{Tissue engineering as regenerative medicine}

\subsection{Background}

Tissue engineering is a rapidly developing area in regenerative medicine which uses knowledge of biological, chemical and engineering techniques to regenerate new tissue invitro (Cooper, Lu et al. 2005). Some tissues in the body are capable of self repair after injury, while others are not, and tissue engineering is a relatively new technique which could offer alternative methods to restore tissues and organ functions (Quaglia 2008). The techniques enable various biophysiological parameters to be controlled in order to develop a functional tissue ready for implantation (Lanza, Langer et al. 2007). The procedure involves using a scaffold to act as a structural support for cell growth and maturation in vitro to eventually produce a functional tissue to repair or replace damaged tissue. This concept was originally developed to repair skin, cartilage and bone, but is now being considered as a possible option to produce neo-ligament tissue rather than using the traditional surgical grafting approach. Although the current methods of treatment may help to fully restore the 
ligaments in some patients, its long-term success in others is unsatisfactory, indicating that there is a need to find more successful, alternative methods of treatment for full restoration of ligaments. Unlike synthetic grafts which can degrade and lose strength over time, tissue engineered implants could perform better in the long term with their biocompatibility, improved integration into surrounding host tissue, and their ability to remodel the ECM as and when required to (Nesic and Whiteside 2006). Tissue engineering also has the advantage of producing an immediately functional tissue (Vunjak-Novakovic, Altman et al. 2004), but the successful incorporation of the soft tissue implant into bone could be a challenge.

For applications in ligament tissue engineering, a scaffold is required to be biocompatible, biodegradable, allow cell adherence, have sufficient surface area and volume for cell ingrowth, be sufficiently strong to withstand mechanical loading forces in vitro and in vivo, and posses a similar stiffness to the native ligament tissue (if it is to be implanted before it degrades) (Christian, Jones et al. 2001 ; Cooper and Lu 2005; Probhakar, Brocchini et al. 2005; Gentleman, Livesay et al. 2006; Sahoo, Ouyang et al. 2006). These points are summarized in table 4. Often, three-dimensional (3-D) scaffolds are preferred to the two-dimensional (2-D) scaffolds because they not only allow cell in-growth, but can also retain cells in their differentiated state. From the literature, it has been reported that fibroblasts cultured in 2-D monolayers have de-differentiated (reverted back to their undifferentiated state) during cell culture (Schulze-Tanzil, Mobasheri et al. 2004), which may not be desirable for tissue engineering purposes.

\begin{tabular}{l|l}
\hline Scaffold requirements & The purpose of this feature \\
\hline Biocompatible & $\begin{array}{l}\text { Avoids immunorejection (a cytotoxic } \\
\text { response could kill the cells) }\end{array}$ \\
\hline Biodegradable & $\begin{array}{l}\text { To degrade at the same rate at which } \\
\text { neotissue forms to avoid the need for } \\
\text { surgical removal }\end{array}$ \\
\hline Enable cell adherence & $\begin{array}{l}\text { To allow cells attachment for growth and } \\
\text { proliferation to occur }\end{array}$ \\
\hline Provide sufficient surface area/volume & $\begin{array}{l}\text { To provide sufficient space for cell spreading } \\
\text { and growth }\end{array}$ \\
\hline Possess comparable strength/stiffness & $\begin{array}{l}\text { To withstand cyclic mechanical loading } \\
\text { forces with magnitudes and strains similar to } \\
\text { those found in vivo }\end{array}$ \\
\hline Surgical implantation & Ease of fixing/bonding to bone (bio-active) \\
\hline
\end{tabular}

Table 4. The main requirements of a scaffold with respect to their application

\subsection{Suitable cell types for ligament tissue engineering}

Fibroblasts and mesenchymal stem cells (MSC's) have been considered to be the preferred cell type for seeding onto scaffolds in tissue engineering (Doroski, Brink et al. 2007). Some 
reports suggest that MSC's are a potentially better source for ligament tissue engineering than ligament fibroblasts due to their higher expression of collagen type I and III (Ge, Goh et al. 2005). Other reports however, feel that ACL fibroblasts are more appropriate because of the characteristic ratios of collagen types produced during tissue repair (Fu, Harner et al. 1993). In one particular study MSC's were isolated from a human ACL and the results demonstrated that both ACL-derived MSC's and bone marrow MSC's expressed marker genes for ligament fibroblasts, but mRNA expression levels for collagen I and III were higher in the ACL-derived MSC's. It was concluded from this study that ACL-derived MSC's have an increased potential to form ligament fibroblasts in comparison to bone marrow MSC's (Huang, Chen et al. 2008). Co-culturing MSC's with ligament fibroblast has been shown to successfully induce MSC differentiation into fibroblasts, where this conclusion was based upon the mRNA expression of key ligament genes (collagen I collagen III, and tenascin-c) and synthesis of these key ligament proteins (Fan, Liu et al. 2008). This feature makes them an attractive cell choice for ligament tissue engineering.

\subsubsection{Mesenchymal stem cells (MSC's)}

Mesenchymal stem cells (MSC's) are multipotent progenitor cells, meaning they can differentiate into specific cell types of various cell lineages. They are found in multiple adult tissue types including bone marrow, muscle, synovial tissue and adipose tissue (Centeno, Busse et al. 2008), where they have the potential to produce cartilage, bone, muscle, tendon, ligament or fat (Papathanasopoulos and Gaiannoudis 2008) in response to the appropriate stimuli (Lanza, Langer et al. 2007). MSC's can be encouraged to move down specific cell lineages by using media which contains hormones such as dexamethasone, hydrocortisone, or growth factors such as transforming growth factor $\beta$ (TGF- $\beta$ ) (Papathanasopoulos and Gaiannoudis 2008), cytokines, transcription factors (Lanza, Langer et al. 2007) or using purely mechanical stimulus (Altman, Horan et al. 2001). MSC's have been used successfully to regenerate articular cartilage in animal models and to regenerate bone in humans (Papathanasopoulos and Gaiannoudis 2008). Because they can be easily isolated and expanded (Papathanasopoulos and Gaiannoudis 2008; Yu, Chen et al. 2008), with the capacity to differentiate, this makes them desirable for tissue engineering applications (Papathanasopoulos and Gaiannoudis 2008). One of the first areas in which they were applied was in tendon and ligament tissue engineering (Lanza, Langer et al. 2007).

Another appealing feature of MSC's is their immunosuppressive and anti-inflammatory effects. They express low levels of major histocompatibility complex (MHC) class I molecules on their surface (preventing natural killer cells deleting them), and no class II MHC, allowing them to escape recognition by alloreactive $\mathrm{T}$ helper cells (Zhao, Liao et al. 2004; Lanza, Langer et al. 2007; Popp, Eggenhofer et al. 2008; Swart, Martens et al. 2008). However, it has been reported that MSC's infused into allogeneic MHC-mismatched mice have been rejected (Swart, Martens et al. 2008). In contrast, this was not the case when genetically modified MSC's were injected into a baboon (Zhao, Liao et al. 2004).

\subsection{Biomaterials suitable for ligament tissue engineering}

To date, many different materials in their various physical forms have been investigated as substrates for tissue engineering applications in general. These include synthetic polymers, natural polymers, glasses, silk, hydrogels, composites and many more. Only those related to ligament tissue engineering, are covered in this chapter (summarized in table 5). 
Synthetic polymers such as polylactic acid, polyglycolic acid and polylactide-co-glycolide (PLA, PGA and PLAGA respectively) are approved by the USA food and drugs agency (FDA) for a variety of clinical applications (Cooper, Lu et al. 2005). These polymers degrade by hydrolysis of ester bonds (water breaks up the molecule), and the components are removed by the natural pathways of the body (Rezwan, Ghen et al. 2006), making them biocompatible. Some of these have been produced into cell scaffolds and tested for their suitability as substrates. PLAGA fibres have been used to make 3-D braided scaffolds, which consisted of 3 regions - the attachment site for the femur bone at one end, the main ligament region in the middle, and the attachment site for the tibia bone at the other end. The results indicated that the scaffold was biocompatible by the observed attachment, spreading and growth of the ACL fibroblasts initially seeded onto it (Cooper, Lu et al. 2005). PLAGA has also been produced into nano-fibres which were electrospun into a knitted PLAGA scaffold to increase the surface area for cell attachment. It significantly improved MSC attachment and proliferation, but also demonstrated that cell function had improved due to the increased mRNA expression of type I collagen and decorin (Sahoo, Ouyang et al. 2006). Braided PLA, PGA and PLAGA have also been found to enhanced rabbit ACL fibroblast attachment and support high cell numbers, being highest on PLA (Lu, Cooper et al. 2005).

Alginates are a natural linear polysaccharide copolymers extracted from brown algae belonging to the phaeophyceae (Hua and Wang 2009). They are currently used in the food, cosmetic and agricultural industries (Hua and Wang 2009). Because they are easy to process, with good biocompatibility and low toxicity, they have been studied in drug stabilization and drug delivery (Lee and Mooney 2001; Drury and Mooney 2003) and for tissue engineering purposes (Sakai, Masuhara et al. 2005), where bone marrow cells have been successfully cultured on them (Wang, Shelton et al. 2003). Other report have also confirmed there suitability by enabling cell adhesion, migration, proliferation and differentiation to take place (Zhao, Deng et al. 2003).

Polyhydroxyalkanoates (PHA's) are currently under investigation for their uses in tissue engineering. They are naturally derived biocompatible polyesters which are produced by microorganisms as carbon and energy stores in unbalanced growing conditions become (Chen and $\mathrm{Wu}$ 2005). They are known to be biocompatible because they are found naturally occurring in mammal blood and tissues, where their purity can be increased by removing long-chain fatty acids and the endotoxin lipopolysaccharide, preventing any adverse reactions (Zhao, Deng et al. 2003; Chen and $\mathrm{Wu}$ 2005). They range from hard and brittle to soft and elastomeric, but can also be blended (combined) with other types of PHA or modified at the surface to alter their mechanical properties and biocompatibility, and produced either as a film or a foam (Rezwan, Ghen et al. 2006). So far, PHA's have been used for a number of different applications including tissue regeneration, repair devices, sutures and bone marrow scaffolds (Shishataskaya, Volova et al. 2004). One report compared the mechanical and surface properties of several modified PHA's and it was concluded that hydrophilicity and a low tackiness were found to be more important than the surface roughness for cell attachment and growth. Substrate stiffness also appeared to influence cell attachment, where the stiffer, more brittle PHA's, retained a significant number of viable cells on their surfaces (Rathbone, Furrer et al. 2009). Because of their diversity in surface texture, flexibility and their biocompatibility, PHA's show potential as cell substrates in tissue engineering. 
Two types of glasses that have been used for medical research are bioglass (developed in the 1969 by Larry Hench) and controlled release glass (CRG) which is a phosphate-based glass, developed in the 1970's. Bioglass does not dissolve completely in fluids, but changes chemically upon its partial degradation, and is currently regarded as the most biocompatible material for bone regeneration due to its bioactivity and osteoconductivity (Wu, Hsu et al. 2009). Unlike bioglass, CRG dissolves completely in fluids at a predetermined rate, leaving no solid residues because phosphorous pentoxide is a main component within its formulation. The metal ions in CRG are found naturally occurring within the body (Probhakar, Brocchini et al. 2005) and upon glass degradation (dissolution) the released ions become removed by the bodies own metabolic system without causing a toxic response, avoiding the need for surgical removal if implanted into the body. Because CRG has a controllable solubility in body fluids and do not need surgical removal, this makes them an ideal scaffold material for promoting neotissue formation in vivo (Ahmed, Lewis et al. 2003). Very little work has been carried out with phosphate based glasses (CRG) for soft tissue engineering, however Bitar and colleagues cultured several cell types, including tendon fibroblasts, upon glass disks with various dissolution rates, where they successfully attached, proliferated while maintaining their phenotype, and it was concluded that the glass (of specific composition) would be ideal scaffold materials for engineering of both hard and soft tissues (Bitar, Salih et al. 2004). In fibrous form, phosphate based glasses have high tensile strength, making them useful for tensile applications, but it is also possible to produce them with dimensions similar to ligament collagen fibres in vivo, particularly the diameter, which can potentially assist cell attachment and spreading. Bitar et al suggested that the fibre diameter of the phosphate based glass which they tested influenced cell attachment (Bitar, Salih et al. 2008).

Many other materials have been investigated. Silk fibroin scaffolds have supported and enhanced ligament- specific differentiation of human MSC's. The silk was cabled into 6cord wire rope matrices, improving its elasticity. The authors suggested that the silk matrix had similar a hierarchical structure to the collagen fibres in native ACL, making the mechanical properties comparable to ACL in stiffness and strength (Wang, Kim et al. 2006). Silk fibroin has also been produced as a microporous silk sponge and incorporated into a knitted silk mesh. After seeding them with rabbit MSC's, the constructs were implanted into rabbits, where at 24 weeks the cells were well distributed throughout a regenerating $\mathrm{ACL}$, and producing key ligament proteins (collagen I and III, and tenacin-c). Also a direct ligament-bone insertion was achieved resembling native ACL-bone insertion (Fan, Liu et al. 2008). Collagen hydrogels have been shown to successfully promote higher production of type I and type III collagen from the cells, where the tissue formation was improved with a ligament-like organisation (Noth, Schupp et al. 2005; Gentleman, Livesay et al. 2006). Poly desamino-tyrosine ethyl carbonate scaffolds have proved to be successful in supporting fibroblast growth while possessing the necessary strength for use as an ACL graft (Laurencin and Freeman 2005).

Composites (consisting of more than one type of material) have also been constructed and analysed. Gelatin with silk fibroin has been produced into microporous sponges around Silk cables, where Fan and colleagues co-cultured rabbit MSC's with ACL fibroblasts on the scaffold, which enabled MSC differentiation into ligament fibroblasts. They detected mRNA expression of collagen type I and III, and tenascin-c with the corresponding protein production (Fan, Liu et al. 2008). 


\begin{tabular}{|c|c|c|c|}
\hline Material & Physical form & Affect on cells/material properties & Author \\
\hline \multicolumn{4}{|l|}{$\begin{array}{l}\text { Synthetic } \\
\text { polymers }\end{array}$} \\
\hline PLAGA & Braided & $\begin{array}{l}\text { Improved fibroblast attachment, } \\
\text { spreading \& growth. }\end{array}$ & $\begin{array}{l}\text { (Cooper, Lu } \\
\text { et al. 2005) }\end{array}$ \\
\hline PLAGA & $\begin{array}{l}\text { Electrospun } \\
\text { PLAGA nano- } \\
\text { fibres onto knitted } \\
\text { PLAGA scaffold. }\end{array}$ & $\begin{array}{l}\text { Improved porcine MSC attachment \& } \\
\text { proliferation. Cells gave higher } \\
\text { expression of type I collagen, decorin } \\
\text { and biglycan genes in comparison to } \\
\text { cells on just a knitted PLAGA } \\
\text { scaffold. }\end{array}$ & $\begin{array}{l}\text { (Sahoo, } \\
\text { Ouyang et al. } \\
\text { 2006) }\end{array}$ \\
\hline $\begin{array}{l}\text { PGA coated with } \\
\text { BioGlass }\end{array}$ & $\begin{array}{l}\text { Mesh coated with } \\
\text { Bioglass. }\end{array}$ & $\begin{array}{l}\text { Increased fibroblast proliferation }(208 \mathrm{f} \\
\text { cell line). }\end{array}$ & $\begin{array}{l}\text { (Day, } \\
\text { Boccaccini et } \\
\text { al. 2004) }\end{array}$ \\
\hline $\begin{array}{l}\text { PLA, PGA, } \\
\text { PLAGA coated } \\
\text { with fibronectin }\end{array}$ & Braided & $\begin{array}{l}\text { Enhanced rabbit ACL fibroblast } \\
\text { adhesion and supported high cell } \\
\text { numbers, (highest for PLA). }\end{array}$ & $\begin{array}{l}\text { (Lu, Cooper } \\
\text { et al. 2005) }\end{array}$ \\
\hline 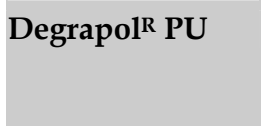 & Fibre-fleece & $\begin{array}{l}\text { Supported fibroblast adhesion \& } \\
\text { proliferation. }\end{array}$ & $\begin{array}{l}\text { (Milleret, } \\
\text { Simonet et al. } \\
\text { 2009) }\end{array}$ \\
\hline \multicolumn{4}{|l|}{ Natural polymers } \\
\hline $\begin{array}{l}\text { Collagen } \\
\text { hydrogel }\end{array}$ & $\begin{array}{l}\text { Hydrogel + } \\
\text { collagen fibres }\end{array}$ & $\begin{array}{l}\text { Increased production of type I \& III } \\
\text { collagen fibres, giving better tissue } \\
\text { formation, and ligament-like } \\
\text { organization in the tissue. }\end{array}$ & $\begin{array}{l}\text { (Noth, } \\
\text { Schupp et al. } \\
\text { 2005; } \\
\text { Gentleman, } \\
\text { Livesay et al. } \\
\text { 2006) }\end{array}$ \\
\hline Silk fibroin & Rope matrix & $\begin{array}{l}\text { Enhanced ligament- specific } \\
\text { differentiation of human MSC's. }\end{array}$ & $\begin{array}{l}\text { (Wang, Kim } \\
\text { et al. 2006) }\end{array}$ \\
\hline Silk fibroin & $\begin{array}{l}\text { Microporous silk } \\
\text { mesh rolled } \\
\text { around braided } \\
\text { silk cord }\end{array}$ & $\begin{array}{l}\text { MSC seeded construct was implanted } \\
\text { into pigs. At } 24 \text { weeks MSC's } \\
\text { differentiated into fibroblast-like cells, } \\
\text { expressing collagen I and III, tenascin-c. }\end{array}$ & $\begin{array}{l}\text { (Fan, Liu et al. } \\
\text { 2009) }\end{array}$ \\
\hline Silk fibroin & $\begin{array}{l}\text { Microporous silk } \\
\text { sponge } \\
\text { incorporated into } \\
\text { knitted silk mesh }\end{array}$ & $\begin{array}{l}\text { Rabbit MSC seeded constructs } \\
\text { implanted into rabbits. At } 24 \text { weeks } \\
\text { cells were well distributed throughout } \\
\text { the regenerating ACL, producing key } \\
\text { ligament proteins (coll I \& III, } \\
\text { Tenascin-c), direct ligament -bone } \\
\text { insertion with } 4 \text { zones was } \\
\text { reconstructed resembling native ACL- } \\
\text { bone insertion. }\end{array}$ & $\begin{array}{l}\text { (Fan, Liu et al. } \\
\text { 2008) }\end{array}$ \\
\hline
\end{tabular}




\begin{tabular}{|c|c|c|c|}
\hline Silk fibroin & $\begin{array}{l}\text { Silk fibroin } \\
\text { electrospun onto } \\
\text { knitted silk base } \\
\text { (random/aligned) }\end{array}$ & $\begin{array}{l}\text { Aligned fibres showed improved cell } \\
\text { proliferation and collagen production } \\
\text { compared to random orientation. }\end{array}$ & $\begin{array}{l}\text { (Teh, Goh et } \\
\text { al. 2008) }\end{array}$ \\
\hline \multicolumn{4}{|l|}{ Composites } \\
\hline $\begin{array}{l}\text { Gelatin + silk } \\
\text { fibroin }\end{array}$ & $\begin{array}{l}\text { Microporous } \\
\text { sponge around } \\
\text { Silk cables }\end{array}$ & $\begin{array}{l}\text { Co-cultured rabbit MSC + ACL } \\
\text { fibroblasts on the scaffold allowing } \\
\text { MSC differentiation into ligament } \\
\text { fibroblasts (mRNA expression of Coll } \\
1 \& 3 \text {, Tenascin-c and corresponding } \\
\text { protein production). }\end{array}$ & $\begin{array}{l}\text { (Fan, Liu et al. } \\
\text { 2008) }\end{array}$ \\
\hline \multicolumn{4}{|l|}{ Glass } \\
\hline $\begin{array}{l}\text { Phosphate-based } \\
\text { glass }\end{array}$ & Disks & $\begin{array}{l}\text { Increased adhesion \& proliferation of } \\
\text { fibroblasts when } \mathrm{CaO} \text { content was } 46- \\
48 \mathrm{~mol} \% \text {. }\end{array}$ & $\begin{array}{l}\text { (Bitar, Salih et } \\
\text { al. 2004) }\end{array}$ \\
\hline $\begin{array}{l}\text { Phosphate-based } \\
\text { glass }\end{array}$ & Fibres & $\begin{array}{l}\text { Increased adhesion \& proliferation of } \\
\text { fibroblasts when } \mathrm{CaO} \text { content was } \\
46 \mathrm{~mol} \% \text {. }\end{array}$ & $\begin{array}{l}\text { (Bitar, } \\
\text { Knowles et al. } \\
\text { 2005) }\end{array}$ \\
\hline Bioactive glass & Disks & $\begin{array}{l}\text { Supported rabbit MSC adherence and } \\
\text { proliferation. }\end{array}$ & $\begin{array}{l}\text { (Meseguer- } \\
\text { Olmo, } \\
\text { Bernabeu- } \\
\text { Esclapez et al. } \\
\text { 2008) }\end{array}$ \\
\hline Collagen fibres & $\begin{array}{l}\text { Braided/plied } \\
\text { (cross-linked) }\end{array}$ & $\begin{array}{l}\text { Implanted into goats, analysed over } \\
11 \text { months post implantation, } \\
\text { concluded they were loosing strength, } \\
\text { therefore not suitable as ACL } \\
\text { substitute. }\end{array}$ & $\begin{array}{l}\text { (Chvapil, } \\
\text { Speer et al. } \\
\text { 1993) }\end{array}$ \\
\hline
\end{tabular}

Table 5. Some of the various different materials previously used as scaffolds (for ligament tissue engineering) their physical forms, and their suitability for cell cultures

\subsection{Material surface modifications using fibronectin}

Because fibronectin is known to function as a cell adhesion protein in vivo, it has been studied in vitro as a method for improving cell attachment. It has been used to modify the surface of various biomaterials to improve cell attachment to the surface, making it useful for tissue engineering. Reports have shown that fibronectin has improved cell retention of rat MSC's on fibronectin-coated surfaces (Dennis and Caplan 1993), increased the adhesive strength of cells, which was probably due to the increased number of bonds between fibroblasts and fibronectin-coated glass slides (Athanassiou and Deligianni 2001). Other studies concluded that braided PLLA and PLAGA polymers coated with fibronectin $(10 \mu \mathrm{g} / \mathrm{ml})$ improved attachment of rabbit ACL cells and effected long term matrix production (Lu, Cooper et al. 2005). From the work carried out by Garcia and colleagues, their results indicated that cell adhesion strength (in osteosarcoma cells) increased on glass surfaces in a concentration-dependent fashion as fibronectin concentrations increased from 
$0.1-1 \mu \mathrm{g} / \mathrm{ml}$. Plates coated with a concentration of $20 \mu \mathrm{g} / \mathrm{ml}$ have been shown to improve cell adhesion of human MSC's in comparison to uncoated plates (Salasznyk, Williams et al. 2004), being more affective than coatings of collagen I or IV. However, in contrast to Salasznyk's findings, Vohra and colleagues who also used a fibronectin concentration of $20 \mu \mathrm{g} / \mathrm{ml}$ (Vohra, Hennessy et al. 2008), suggested that although the fibronectin coating improved cell attachment compared to the negative control, MSC's preferred to attach to a collagen I coating in comparison to the fibronectin and negative control.

\subsection{Bioreactor culture of tissue engineered ligaments}

A bioreactor is a vessel designed to contain cultures, where the environmental conditions can be optimised and carefully controlled to encourage certain biological and biochemical processes to take place (Martin, Wendt et al. 2004). Currently, many different types of bioreactors exist. They can be used to improve mass transfer of nutrients, waste products and oxygen through the culture medium, improve cell attachment, cell growth and proliferation. Bioreactors have been used in tissue engineering to apply mechanical forces to cell constructs (mechanical loading), and reported to promote differentiation of mesenchymal stem cells (MSC) into ligament fibroblasts (Zhang, Wang et al. 2004; Meyer, Buchter et al. 2005), induce alignment of fibroblasts with the direction of the applied force, upregulate mRNA expression of key ligament genes and produce helically organized collagen fibres (Altman, Horan et al. 2001). Mechanical conditioning can also be used to improve the structural and functional properties of a tissue once it has been engineered. Only those bioreactors related to ligament tissue engineering will be discussed here.

When forces are applied to cells, the magnitude of the applied force, the way in which it is applied (constantly or alternating), the duration of time and the direction of forces (translational or rotational) will have a specific effect upon cell behaviour. These complex forces are experienced by the native tissue under physiological conditions. A specific combination or sequence of any of these can influence the cell to give a positive or negative response. Therefore variations in mechanical loading regimens can affect and alter the gene expression, and hence protein production and regulate tissue formation (Nesic, Whiteside et al. 2006).

\section{Response of cells to mechanical stimuli in vitro}

Many in vitro studies investigating the affects of mechanical loading have been performed with bioreactors. Kaplan and colleagues used a bioreactor to apply mechanical stimulation to mesenchymal progenitor cells seeded into a collagen 3-D gel matrix. The bioreactor applied multidimensional forces concurrently - translational $(2 \mathrm{~mm})+$ rotational $\left(90^{\circ}\right)$ - at a frequency of $0.0167 \mathrm{~Hz}$ (one complete cycle of stress and relaxation per minute) constantly for 21 days, which was chosen to mimic the unique combination of forces experienced by the ligament under physiological conditions in vivo (Altman, Horan et al. 2001). Their results induced cell alignment parallel to the direction of the stretching force with an elongated cell morphology, mRNA expression of specific genes (type I and III collagen, tenascin-c and fibronectin), helically organized type I collagen fibres orientated in the direction of force, with the selective differentiation of human MSC's into a ligament cell lineage rather than towards alternative lineages. The controls (non- loaded cells), showed few of these features. They concluded that "the mechanical forces could play a role in differentiation and not just promote formation of specific tissue types from the already 
differentiated cells" and "the mechanical stimulation appeared to cause a selective differentiation to ligament-like cells" (Altman, Horan et al. 2001). Mechanical cyclic loading in compressed acellular collagen gels has been reported to encourage collagen fibril aggregation, promote fusion, resulting in an increase in its mechanical strength (Cheema, Chuo et al. 2007). Table 6 summarizes some of the mechanical loading conditions carried out in various studies, and the effects which they had upon the cells.

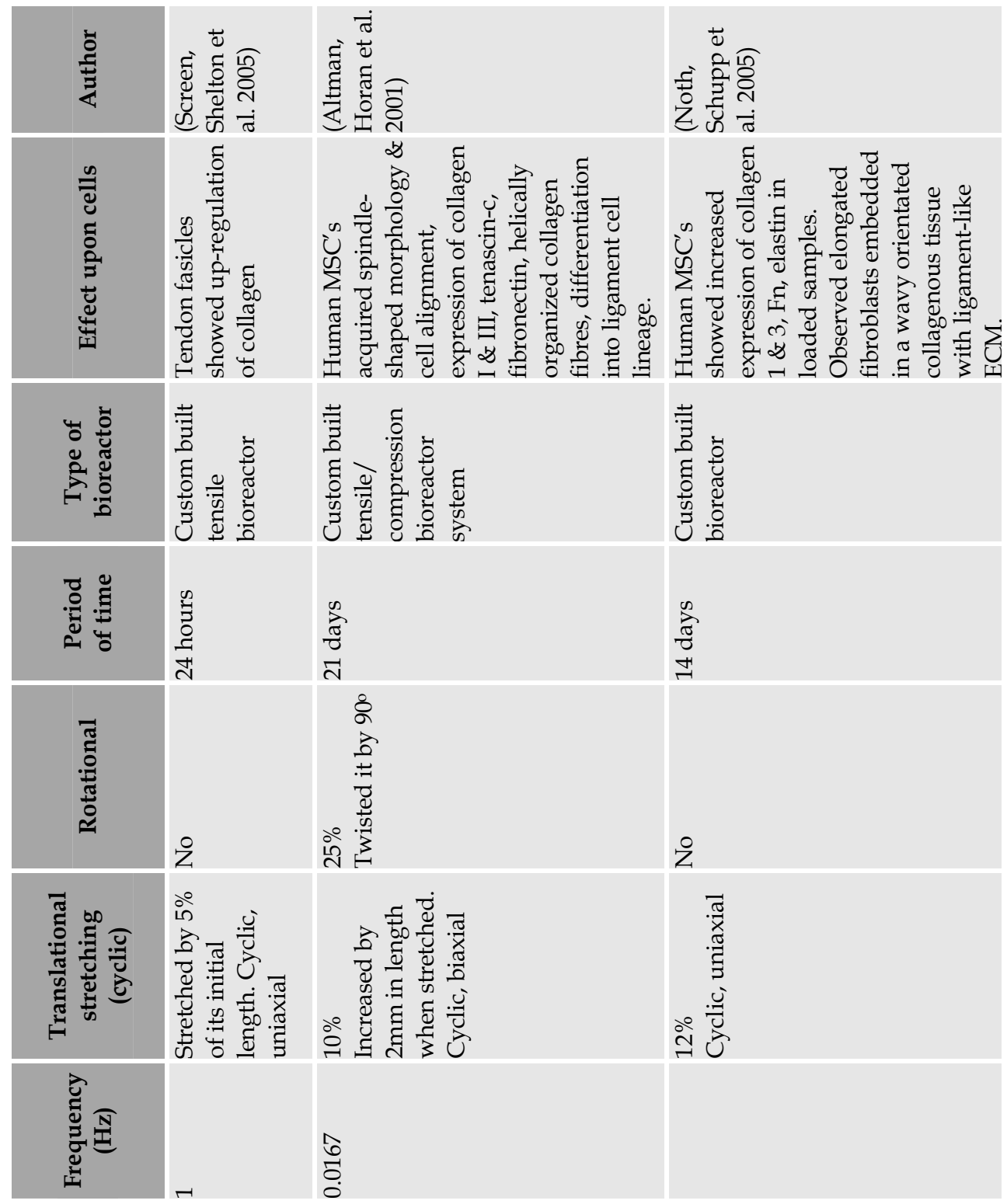




\begin{tabular}{|c|c|c|c|c|c|}
\hline & 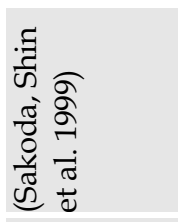 & 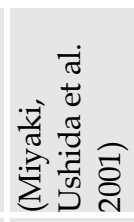 & 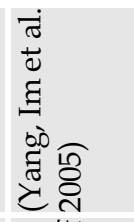 & 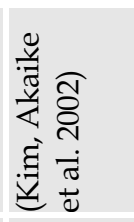 & 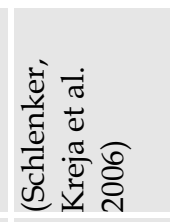 \\
\hline 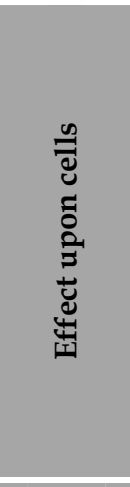 & 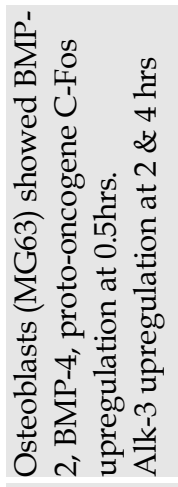 & 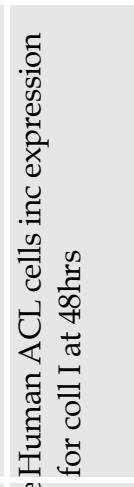 & 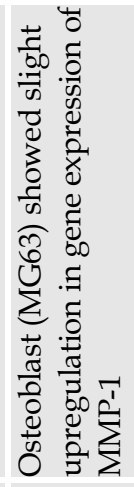 & 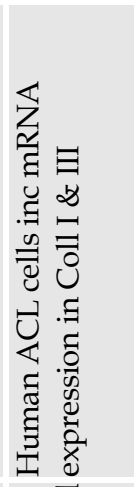 & 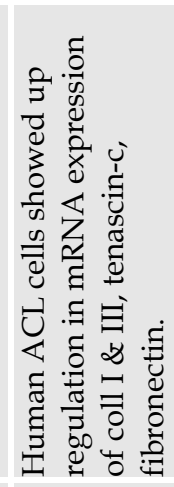 \\
\hline 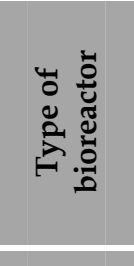 & 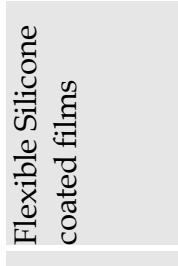 & 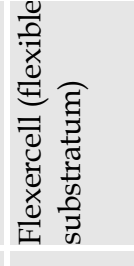 & 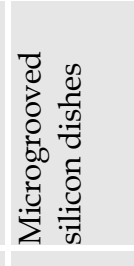 & 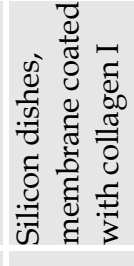 & \\
\hline 莺 苛 & 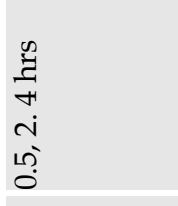 & 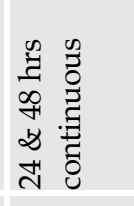 & $\frac{\mathscr{D}}{\not{Z}}$ & \begin{tabular}{l}
$\stackrel{0}{\Xi}$ \\
\multirow{J}{*}{}
\end{tabular} & 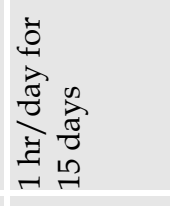 \\
\hline 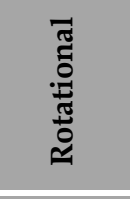 & ż & ż & $\stackrel{\circ}{Z}$ & 之े & 之े \\
\hline 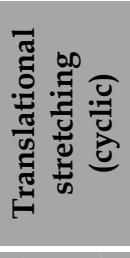 & 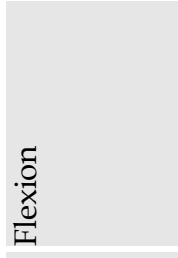 & 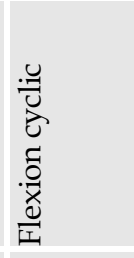 & 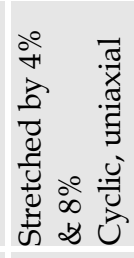 & 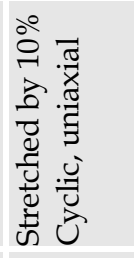 & 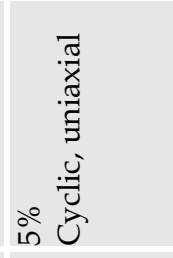 \\
\hline 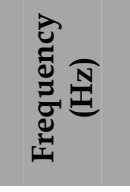 & $\stackrel{10}{0}$ & $\begin{array}{l}\hat{0} \\
\stackrel{0}{0}\end{array}$ & L̊? & 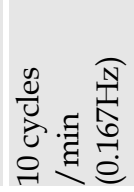 & \\
\hline
\end{tabular}




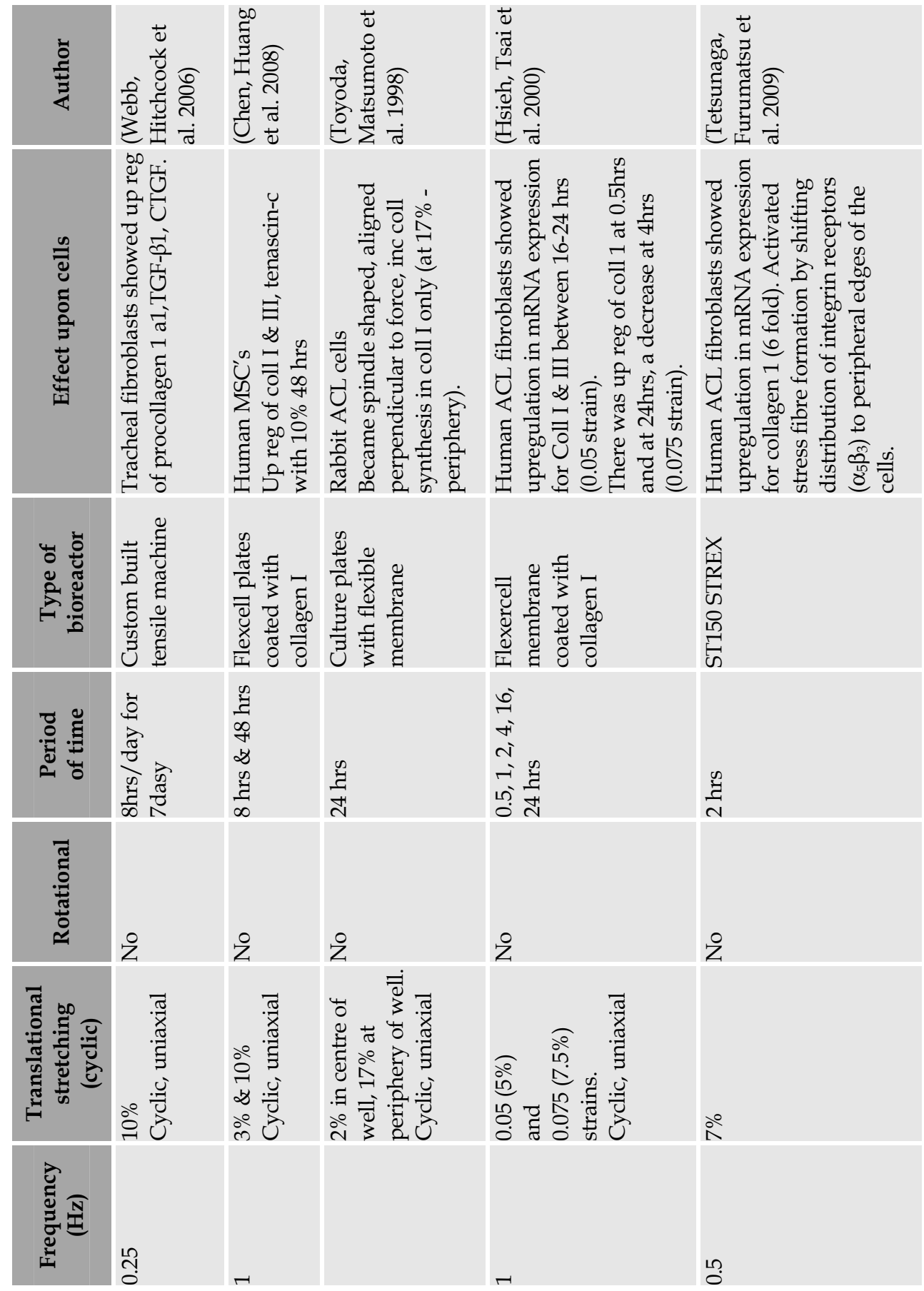




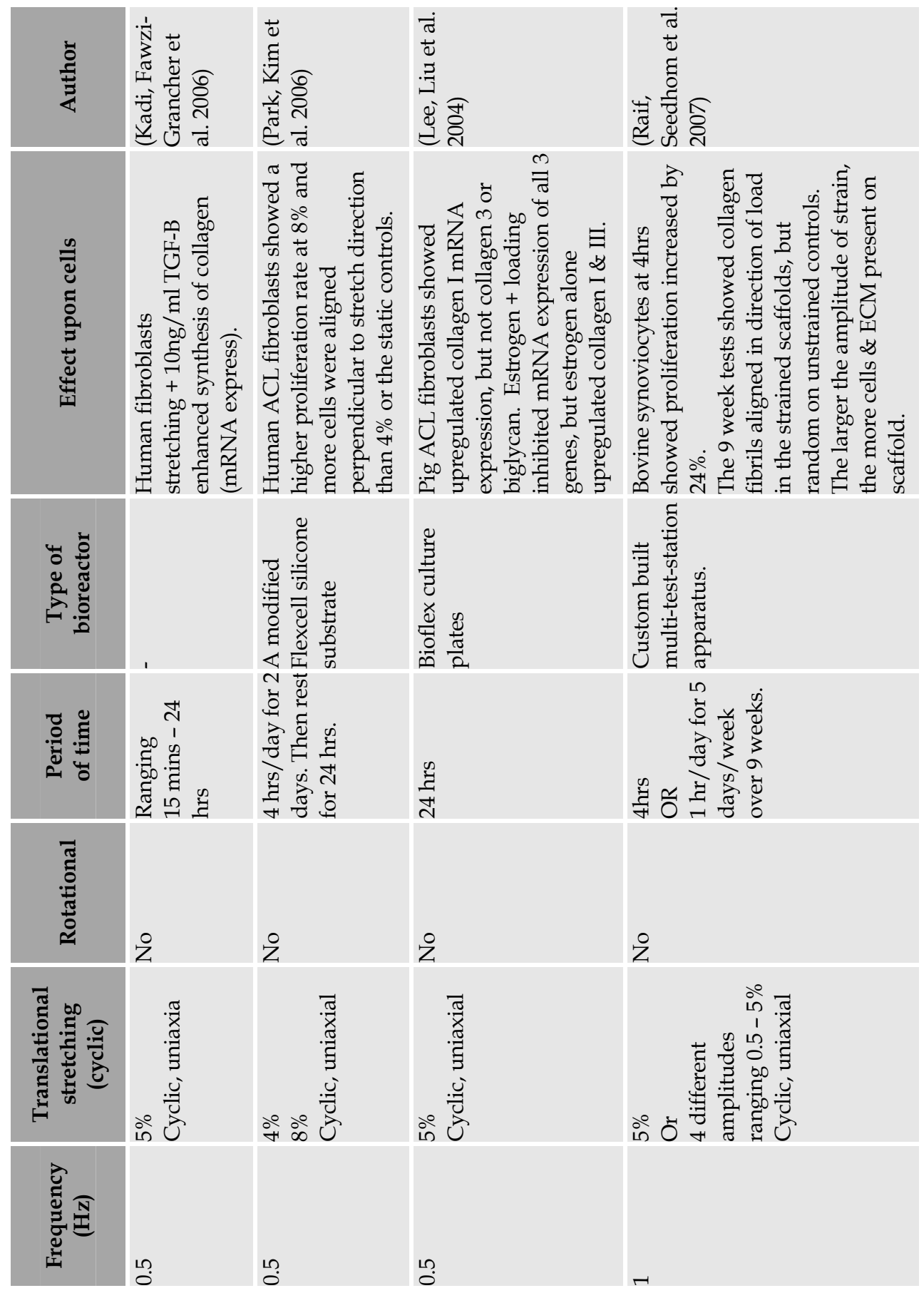




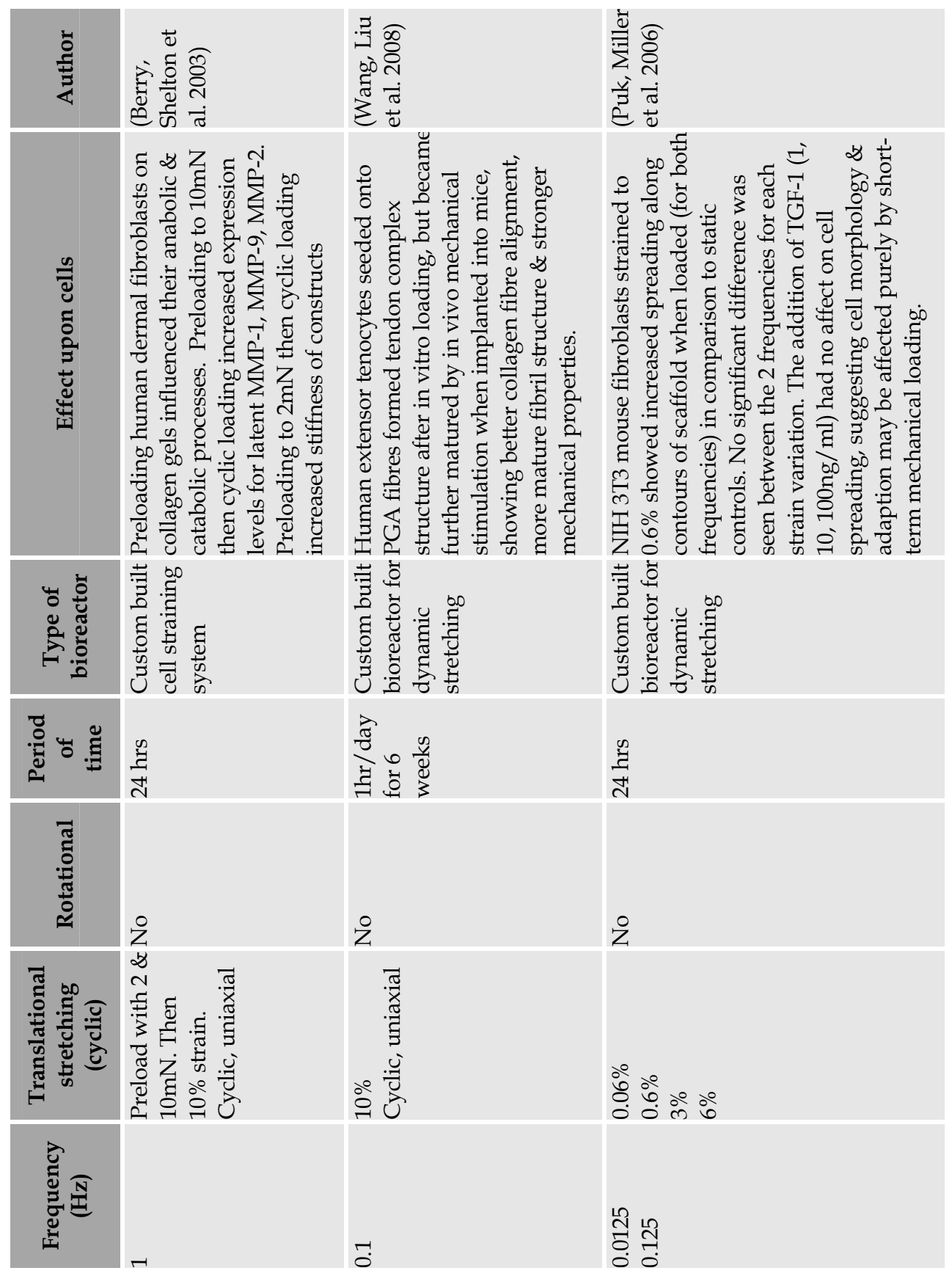

Table 6. The mechanical loading regimens which have been applied to tissue engineered constructs in vitro and the effects they have had upon various cell types 


\begin{tabular}{|c|c|c|c|c|}
\hline Cell type & $\begin{array}{c}\text { TGF } \\
\text { concentration }\end{array}$ & $\begin{array}{l}\text { Combined with } \\
\text { other GF's }\end{array}$ & Effects & Author \\
\hline MSC & $\begin{array}{l}\text { hr TGF- } \beta 1 \\
10 \mathrm{ng} / \mathrm{ml} \\
\text { Static culture }\end{array}$ & & $\begin{array}{l}\text { 10ng/ml increased GAG } \\
\text { expression \& } \\
\text { proliferation after } \\
\text { 14days, whereas } 0.1- \\
1 \mathrm{ng} / \mathrm{ml} \text { did not. }\end{array}$ & $\begin{array}{l}\text { (Chen, Tsai et } \\
\text { al. 2005) }\end{array}$ \\
\hline $\begin{array}{l}\text { h ACL } \\
\text { explants }\end{array}$ & $\begin{array}{l}\text { TGF- } \beta 1 \\
0.6 \mathrm{ng} / \mathrm{ml} \\
\text { Static culture }\end{array}$ & $\begin{array}{l}\text { Ascorbic acid } \\
25 \mathrm{ug} / \mathrm{ml}\end{array}$ & $\begin{array}{l}\text { Cell number increased. } \\
\text { Collagen production } \\
\text { increased by } 3 \text { times. }\end{array}$ & $\begin{array}{l}\text { (Meaney } \\
\text { Murray, Rice } \\
\text { et al. 2003) }\end{array}$ \\
\hline h MSC & $\begin{array}{l}\text { TGF- } \beta \\
5 \mathrm{ng} / \mathrm{ml} \\
\text { Static culture }\end{array}$ & $\begin{array}{l}\text { TGF+Insulin } \\
\text { Adding ascorbic } \\
\text { acid to TGF } \\
\text { promoted } \\
\text { greatest ratio of } \\
\text { collagen: total } \\
\text { protein } \\
\text { production }\end{array}$ & $\begin{array}{l}\text { TGF alone encouraged } \\
\text { differentiation into } \\
\text { fibroblasts (regarding } \\
\text { morphology \& } \\
\text { alignment). Collagen } 1 \\
\text { \& } 3 \text { express increased. } \\
\text { Negligible expression of } \\
\text { BSP \& OSP. }\end{array}$ & $\begin{array}{l}\text { (Moreau, } \\
\text { Chen et al. } \\
\text { 2005) }\end{array}$ \\
\hline h MSC & $\begin{array}{l}\text { TGF- } \beta \\
0.1,0.5,1,5 \\
\text { ng/ml } \\
\text { Static culture }\end{array}$ & & $\begin{array}{l}\text { Proliferation rate } \\
\text { increased as } \\
\text { concentration increased } \\
(0.1-5 \mathrm{ng} / \mathrm{ml}) \text {. } \\
\text { 1ng/ml TGF + FCS } \\
\text { increased matrix } \\
\text { production. }\end{array}$ & $\begin{array}{l}\text { (Locklin, } \\
\text { Oreffo et al. } \\
1998)\end{array}$ \\
\hline $\begin{array}{l}\text { Rabbit ACL } \\
\text { fibroblasts }\end{array}$ & $\begin{array}{l}\text { TGF- } \beta 1 \\
0.01,0.1,1 \mathrm{ng} / \mathrm{ml} \\
\text { Static culture }\end{array}$ & & $\begin{array}{l}\text { Increased collagen \& } \\
\text { non-collagenous protein } \\
\text { synthesis as } \\
\text { concentration increased, } \\
\text { highest being at } 1 \mathrm{ng} / \mathrm{ml} \text {. } \\
\text { The increase was mostly } \\
\text { for collagen } 1 \text { which } \\
\text { increased by } 1.5 \text { times. }\end{array}$ & $\begin{array}{l}\text { (Marui, } \\
\text { Niyibizi et al. } \\
\text { 1997) }\end{array}$ \\
\hline $\begin{array}{l}\text { Sheep ACL } \\
\text { explants }\end{array}$ & $\begin{array}{l}\text { hr TGF- } \beta 1 \\
\text { 10, 50, 100ng/ml } \\
\text { Static culture }\end{array}$ & & $\begin{array}{l}\text { Increased proliferation } \\
\text { (seen at } 96 \mathrm{hrs} \text { ). }\end{array}$ & $\begin{array}{l}\text { (Spindler, } \\
\text { Imro et al. } \\
\text { 1996) }\end{array}$ \\
\hline $\begin{array}{l}\text { Human and } \\
\text { rabbit } \\
\text { mesenchymal } \\
\text { progenitor } \\
\text { cells }\end{array}$ & $\begin{array}{l}\text { hr TGF- } \beta 1 \\
\text { Static culture }\end{array}$ & & Chondrogenic & $\begin{array}{l}\text { (Chen, Tsai et } \\
\text { al. 2005) }\end{array}$ \\
\hline
\end{tabular}

Table 7. The effects of TGF- $\beta 1$ upon fibroblasts and MSC's 


\section{Response of cells to chemical stimuli in vitro}

During a cells life cycle, the cell needs to receive the appropriate signals at specific time points to instruct it to grow, proliferate, differentiate or synthesise ECM. These chemical signals are often provided by growth and differentiation factors. They bind the cell surface receptors on target cells to activate specific intracellular signalling pathways, controlling cell growth, proliferation, migration and differentiation (Quaglia 2008). The effect that a differentiation or growth factor has upon a cell can vary depending on the cell type, the stage in the cells life cycle and its environmental conditions. Such an example is transforming growth factor- $\beta$ (TGF- $\beta$ ) which can be an inhibitor or stimulator of inflammation, or ECM remodelling by inducing mRNA expression of integrins, collagen and fibronectin (Evans 1999).

In order for tissue engineering to be successful, it is necessary to create an artificial environment for the cells, and possibly mimic the in vivo environment, to promote formation of new tissue. Such an environment can be created by using, not only a suitable scaffold or mechanical stimulus, but also a chemical stimulus by incorporating growth factors into the culture media (Tabata 2003). From published research work, many authors report using various different growth factors such as basic fibroblast growth factor (bFGF), platelet derived growth factor (PDGF), transforming growth factor- $\beta 1$ (TGF- $\beta 1$ ), epidermal growth factor (EGF) and insulin-like growth factor (IGF) to encourage cells to proliferate, differentiate or increase the production of collagen (Schmidt, Georgescu et al. 1995; Spindler, Imro et al. 1996; Scherping, Schmidt et al. 1997; Murray, Rice et al. 2003; Pertigliano, McAllister et al. 2006). In vitro cell culture studies which used bFGF, PDGF, EGF or TGF- $\beta 1$ individually, have shown them to increase the proliferation of ACL fibroblasts (Schmidt, Georgescu et al. 1995; Spindler, Imro et al. 1996; Scherping, Schmidt et al. 1997; Murray, Rice et al. 2003), whereas a combination of TGF with bFGF or EGF has promoted MSC differentiation into fibroblasts (Pertigliano, McAllister et al. 2006). Growth factors have also been identified for their roles in regulating healing and repair of connective tissue after injury (Spindler, Imro et al. 1996). It is thought that the response of musculoskeletal tissues to injury or mechanical stress is modulated by growth factors such as PDGF and TGF- $\beta$ (Spindler, Imro et al. 1996).

\subsection{In vitro studies with TGF- $\beta 1$}

TGF- $\beta 1$ has been used in various studies ranging in concentration from $0.1-15 \mathrm{ng} / \mathrm{ml}$. Specific concentrations have been shown to increase fibroblast proliferation, increase collagen production, glycosaminoglycan expression, and encourage MSC's to differentiate into fibroblasts (Spindler, Imro et al. 1996; Locklin, Oreffo et al. 1998; Meaney Murray, Rice et al. 2003; Chen, Tsai et al. 2004; Chen, Tsai et al. 2005; Moreau, Chen et al. 2005; Giannouli and Kletsas 2006; Marenzara, Wilson-Jones et al. 2006). Table 7 summarises the effects that different concentrations of TGF- $\beta 1$ have had on fibroblasts and MSC's.

\section{Characterisation of a tissue engineered ligament}

When creating a tissue-engineered ligament, it is important to be aware of the characteristic components and properties found in native ligament as a comparing standard for functionality (shown in table 1). The ACL characteristics are demonstrated below in table 8 . 
The variation in tensile strength has been correlated to age and gender, where strength and stiffness of the ACL has been found to be lower in adult females (Chandrashekar, Mansouri et al. 2006), and can also significantly reduce as age increases, being 2-3 times higher in younger people, aged 16-26 years, compared to those aged at approximately 60 years old (Noyes and Grood 1976).

\begin{tabular}{|c|c|c|c|c|c|}
\hline $\begin{array}{l}\text { Collagen fibre } \\
\text { arrangement }\end{array}$ & $\begin{array}{c}\text { Fibroblast } \\
\text { distribution and } \\
\text { orientation }\end{array}$ & $\begin{array}{l}\text { Tensile } \\
\text { strength - } \\
\text { maximum } \\
\text { force upon } \\
\text { ACL at } \\
\text { failure (N) }\end{array}$ & $\begin{array}{c}\text { Maximum } \\
\text { elongation } \\
\text { of ACL at } \\
\text { failure }(\mathrm{mm})\end{array}$ & $\begin{array}{l}\text { Stiffness - } \\
\text { Young's } \\
\text { modulus } \\
\text { of } \\
\text { elasticity } \\
\text { (MPa) }\end{array}$ & Author \\
\hline $\begin{array}{l}\text { Aligned in a } \\
\text { fairly parallel } \\
\text { orientation } \\
\text { with the } \\
\text { longitudinal } \\
\text { axis of the } \\
\text { ligament }\end{array}$ & $\begin{array}{l}\text { Sparsely } \\
\text { distributed } \\
\text { throughout the } \\
\text { ECM } \\
\text { (approximately } \\
20 \% \text { if the tissue } \\
\text { volume), } \\
\text { aligned on } \\
\text { collagen fibre } \\
\text { bundles }\end{array}$ & $556-1730$ & $8-12$ & $9-13$ & $\begin{array}{l}\text { (Noyes and } \\
\text { Grood 1976; } \\
\text { Laurencin, } \\
\text { Ambrosio et al. } \\
\text { 1999; Azangwe, } \\
\text { Mathias et al. } \\
\text { 2001; } \\
\text { Chandrashekar, } \\
\text { Mansouri et al. } \\
\text { 2006; Doroski, } \\
\text { Brink et al. 2007) }\end{array}$ \\
\hline
\end{tabular}

Table 8. Fibre organisation and mechanical properties of the ACL

\section{Conclusions}

Tissue engineering of ligaments is still in its early stages, but its prospects have great potential. Tissue engineering has the ability to overcome the limitations of autografts and allografts by generating a tissue with the correct structural and biomechanical properties for a more successful transplant, hopefully giving a better long-term mechanical performance. The benefits of using autologous cells from the patient reduces the risk of tissue rejection or transmission of infectious diseases associated with allografts, and also avoids donor site morbidity associated with allografts. Advances in research in this area continue to optimise a combination of the factors discussed in this chapter such as choice of biomaterial, cell type and stimuli for potential synergistic effects.

\section{References}

Ahmed, I., C. Collins, et al. (2004). Processing, characterisation and biocompatibility of ironphosphate glass fibres for tissue engineering. Biomaterials 25(16): 3223-3232.

Ahmed, I., M. Lewis, et al. (2003). Phosphate glasses for tissue engineering: Part 2. Processing \& characterisation of a ternary-based $\mathrm{P}_{2} \mathrm{O}_{5}-\mathrm{CaO}-\mathrm{Na}_{2} \mathrm{O}$ glass fibre system. Biomaterials 25(3): 501-507. 
Alberts, B., A. Johnson, et al. (2000). Molecular Biology of the Cell 4th Edition, Garland Science.

Altman, G., R. Horan, et al. (2001). Cell differentiation by mechanical stress. FASEB Journal 16: 270-272.

Altman, G., H. Lu, et al. (2002). Advanced bioreactor with controlled application of multidimensional strain for tissue engineering. Journal of Biomechanical engineering 124: 742-749.

Arnoczky, P. (1983). Anatomy of the anterior cruciate ligament. Clinical orthopaedics and related research 172: 19-25.

Athanassiou, G. and D. Deligianni (2001). Adhesion strength of individual human bone marrow cells to fibronectin. Integrin $\beta_{1}$-mediated adhesion. Journal of Material Science: Materials in Medicine 12: 965-970.

Azangwe, G., K. Mathias, et al. (2001). Preliminary comparison of the rupture of human and rabbit anterior cruciate ligaments. Clinical Biomechanics 16(10): 913-917.

Beasley, L., D. Weiland, et al. (2005). Anterior cruciate ligament reconstruction: A literature review of the anatomy, biomechanics, surgical considerations, and clinical outcomes. Operative Techniques in Orthopaedics 15(1): 5-19.

Berry, C., J. Shelton, et al. (2003). Influence of external uniaxial cyclic strain on oriented fibroblast-seeded collagen gels. Tissue Engineering 9(4): 613-624.

Bitar, M., J. Knowles, et al. (2005). Soluble phosphate glass fibres for repair of bone-ligament interface. Journal of materials science. Materials in medicine 16: 1131-1136.

Bitar, M., V. Salih, et al. (2008). Iron-phosphate glass fiber scaffolds for the hard-soft interface regeneration: The effect of fiber diameter and flow culture condition on cell survival and differentiation. Journal of Biomedical Materials Research A 87(4): 1017-1026.

Bitar, M., V. Salih, et al. (2004). Soluble phosphate glasses in vitro studies using human cells of hard and soft tissue origin. Biomaterials 25(12): 2283-2292.

Carpenter, J. and K. Hankenson (2004). Animal models of tendon and ligament injuries for tissue engineering applications. Biomaterials 25(9): 1715-1722.

Centeno, J., D. Busse, et al. (2008). Regeneration of meniscus cartilage in a knee treated with percutaneously implanted autologous mesenchymal stem cells. Medical Hypotheses 71: 900-908.

Chandrashekar, N., H. Mansouri, et al. (2006). Sex-based differences in the tensile properties of the human anterior cruciate ligament. Journal of biomechanics 39(16): 2943-2950.

Cheema, U., C.-B. Chuo, et al. (2007). Engineering functional collagen scaffolds: Cyclic loading increases material strength and fibril aggregation. Advanced Functional Materials 17: 2426-2431.

Chen, C., Y. Tsai, et al. (2005). Type I and II collagen regulation of chondrogenic differentiation by mesenchymal progenitor cells. Journal of Orthopaedic Research 23: 446-453.

Chen, G. and Q. Wu (2005). The application of polyhydroxyalkanoates as tissue engineering materials. Biomaterials 26(33): 6565-6578.

Chen, Y., C. Huang, et al. (2008). Effects of cyclic mechanical stretching on the mRNA expression of tendon/ligament-related and osteoblast-specific genes in human mesenchymal stem cells. Connective tissue Research 49(1): 7-14. 
Chiquet, M., A. Sarasa-Renedo, et al. (2003). How do fibroblasts translate mechanical signals into changes in extracellular matrix production? Matrix Biology 22(1): 73-80.

Christian, P., I. Jones, et al. (2001 ). Monomer transfer moulding and rapid prototyping methods for fibre reinforced thermoplastics for medical applications. Composites part A: Applied science and manufacturing 32(7): 969-976.

Chuen, F., C. Chuk, et al. (2004). Immunohistochemical characterization of cells in adult human patellar tendons. Journal of Histochemistry and Cytochemistry 52(9): 1151-1157.

Chvapil, M., D. Speer, et al. (1993). Collagen fibres as a temporary scaffold for replacement of ACL in goats. Journal of Biomedical Materials Research 27: 313-325.

Cooper, J. and L. Bailey (2006). Evaluation of the anterior cruciate ligament, medial collateral ligament, Achilles tendon and patellar tendon as cell sources for tissue-engineered ligament. Biomaterials 27: 2747-2754.

Cooper, J., H. Lu, et al. (2005). Fiber-based tissue-engineered scaffold for ligament replacement: design considerations and in vitro evaluation. Biomaterials 26(13): 1523-1532.

Day, R., A. Boccaccini, et al. (2004). Assessment of polyglycolic acid mesh and bioactive glass for soft-tissue engineering scaffolds. Biomaterials 25(27): 5857-5866.

Dennis, J. and A. Caplan (1993). Porous ceramic vehicles for rat-marrow-derived (Rattus norvegicus) osteogenic cell delivery: Effects of pre-treatment with fibronectin or laminin. Journal of Oral Implantology XIX(2): 106-115.

Doroski, D. and D. Brink (2007). Techniques for biological characterization of tissueengineered tendon and ligament. Biomaterials 28(2): 187-202.

Drury, J. and D. Mooney (2003). Hydrogels for tissue engineering: scaffold design variables and applications. Biomaterials 24: 4337-4351.

Einhorn, T., R. O'Keefe, et al. (2007). Orthopaedic basic science. Foundations of clinical practice, American Academy of Orthopaedic Surgeons (AAOS).

Ellenbecker, T. (2000). Knee ligament rehabilitation. New York, Churchill Livingstone. New York.

Evans, C. (1999). Cytokines and the role they play in the healing of ligaments and tendons. Current opinion Sports medicine 28(2): 71-76.

Fan, H., H. Liu, et al. (2008). Enhanced differentiation of mesenchymal stem cells co-cultured with ligament fibroblasts on gelatin/silk fibroin hybrid scaffold. Biomaterials 29: 1017-1027.

Fan, H., H. Liu, et al. (2009). Anterior cruciate ligament regeneration using mesenchymal stem cells and silk scaffold in large animal model. Biomaterials 30(28): 4967-4977.

Fan, H., H. Liu, et al. (2008). In vivo study of anterior cruciate ligament regeneration using mesenchymal stem cells and silk scaffolds. Biomaterials 29: 3324-3337.

Fenwick, S., B. Hazleman, et al. (2002). The vasculature and its role in the damaged and healing tendon. Arthritis Research 4(4): 252-260.

Foster, A., C. Butcher, et al. (2005). Changes in arthroscopic findings in the anterior cruciate ligament deficient knee prior to reconstructive surgery. The Knee 12(1): 33-35.

Fu, F., C. Harner, et al. (1993). Biomechanics of knee ligaments. The Journal of Bone and Joint Surgery 75-A: 11.

Fulton, A. (1984). The cytoskeleton-cell architecture and choreography, Chapman \& Hall London. 
Ge, Z., J. Goh, et al. (2005). Selection of cell source for ligament tissue engineering. Cell transplant 14(8): 573-583.

Gentleman, E., G. Livesay, et al. (2006). Development of ligament-like structural organization and properties in cell-seeded collagen scaffolds in vitro. Annals of Biomedical engineering 34(5): 726-736.

Goulet, F., L. Germain, et al. (1997). Principles of tissue engineering. The need for bioengineered tendons \& ligaments RG Landes company.

Hairfield-Stein, M., C. England, et al. (2007). Development of self-assembled tissue engineered ligament from bone marrow stromal cells. Tissue Engineering 13(4): 703710.

Hansen, U., S. Masouros, et al. (2006). (iii) Material properties of biological tissues related to joint surgery. Current Orthopaedics 20(1): 16-22.

Hsieh, A., C. Tsai, et al. (2000). Time-dependent increases in type III collagen gene expression in medial collateral ligament fibroblasts under cyclic strains. Journal of Orthopaedic Research 18: 220-227.

Hua, S. and A. Wang (2009). Synthesis, characterisation and swelling behaviours of sodium alginate-g-poly(acrylic acid)/sodium humate superabsorbent. Carbohydrate Polymers 75: 79-84.

Huang, T., Y. Chen, et al. (2008). Isolation and characterization of mesenchymal stromal cells from human anterior cruciate ligament. Cytotherapy 10(8): 806-814.

Ingber, D. (1999). How cells (might) sense microgravity. Faseb 13: S3-S15.

Johansson, S., G. Svineng, et al. (1997). Fibronectin-Integrin interactions. Frontiers in Bioscience 2: d126-146.

Kadi, A., S. Fawzi-Grancher, et al. (2006). Effect of cyclic stretching and TGF-beta pathway on the extra cellular matrix synthesis in tissue engineering. Journal of Biomechanics 39(Suppl 1): S579-580.

Kim, S.-G., T. Akaike, et al. (2002). Gene expression of type I and type III collagen by mechanical stretch in anterior cruciate ligament cells. . Cell Structure and Function 27: 139-144.

Lanza, R., R. Langer, et al. (2007). Principles of Bone Tissue Engineering - Tendons \& Ligaments. Third edition, Elsevier Inc.

Laurencin, C., A. Ambrosio, et al. (1999). Tissue engineering: Orthopaedic applications. Annual Review of Biomedical engineering 1: 19-46.

Laurencin, C. and J. Freeman (2005). Ligament tissue engineering: An evolutionary materials science approach. Biomaterials 26: 7530-7536.

Lee, C.-Y., X. Liu, et al. (2004). The combined regulation of estrogen and cyclic tension on fibroblast biosynthesis derived from anterior cruciate ligament. Matrix Biology 23: 323-329.

Lee, K. and D. Mooney (2001). Hydrogels for tissue engineering. Chemical Reviews 101(7): 1873-1886.

Locklin, R., R. Oreffo, et al. (1998). Effects of TGF- $\beta$ and bFGF on the differentiation of human bone marrow stromal fibroblasts. Cell Biology International 23(3): 185-194.

Lu, H., J. Cooper, et al. (2005). Anterior cruciate ligament regeneration using braided biodegradable scaffolds: in vitro optimization studies. Biomaterials 26(23): 48054816. 
Martin, I., D. Wendt, et al. (2004). The role of bioreactors in tissue engineering. Trends in Biotechnology 22(2): 80-86.

Marui, T., C. Niyibizi, et al. (1997). Effect of growth factors on matrix synthesis by ligament fibroblasts. Journal of Orthopaedic Research 15(1): 18-23.

Mascarenhas, R. and P. MacDonald (2008). Anterior cruciate ligament reconstruction: A look at prosthetics - past, present and possible future. McGill Journal of Medicine 11(1): 2937.

Matyas, J., P. Edwards, et al. (1994). Ligament tension affects nuclear shape in situ: An in vitro study. Connective Tissue Research 31(1): 45-53.

Meaney Murray, M., K. Rice, et al. (2003). The effect of selected growth factors on human anterior cruciate ligament cell interactions with a three-dimensional collagen-GAG scaffold. Journal of Orthopaedic Research 21(2): 238-244.

Meseguer-Olmo, L., A. Bernabeu-Esclapez, et al. (2008). In vitro behaviour of adult mesenchymal stem cells seeded on a bioactive glass ceramic in the $\mathrm{SiO}_{2}-\mathrm{CaO}-\mathrm{P}_{2} \mathrm{O}_{5}$ system. Acta Biomaterialia 4: 1104-1113.

Meyer, U., A. Buchter, et al. (2005). Design and performance of a bioreactor system for mechanically promoted three-dimensional tissue engineering. British Journal of Oral and Maxillofacial surgery 44(2): 134-140.

Milleret, V., M. Simonet, et al. (2009). Cyto- and hemocompatibility of a biodegradable 3Dscaffold material designed for medical applications. Journal of Biomedical Materials Research B Applied Biomaterials 91B(1): 109-121.

Miyaki, S., T. Ushida, et al. (2001). Mechanical stretch in anterior cruciate ligament derived cells regulates type I collagen and deocrin expression through extracellular signalregulate kinase 1/2 pathway. Materials Science and Engineering C 17: 91-94.

Miyazaki, H., Y. Hasegawa, et al. (2000). A newly designed tensile tester for cells \& its applications to fibroblasts. Journal of Biomechanics 33(1): 97-104.

Moreau, J., J. Chen, et al. (2005). Growth factor induced fibroblast differentiation from human bone marrow stromal cells in vitro. Journal of Orthopaedic Research 23: 164174.

Murray, M., K. Rice, et al. (2003). The effect of selected growth factors on human anterior cruciate ligament cell interactions with a three-dimensional collagen-GAG scaffold. Journal of orthopaedic research 21(2): 238-244.

Nesic, D., R. Whiteside, et al. (2006). Cartilage tissue engineering for degenerative joint disease. Advanced drug delivery reviews 58(2): 300-322.

Noth, U., K. Schupp, et al. (2005). Anterior cruciate ligament constructs fabricated from human mesenchymal stem cells in a collagen type I hydrogel. Cytotherapy 7(5): 447455.

Noyes, F. and E. Grood (1976). The strength of the anterior cruciate ligament in humans and Rhesus monkeys. The Journal of bone and joint surgery 58-A(8): 1074-1081.

Pankov, R. and K. Yamada (2002). Fibronectin at a glance. Journal of Cell Science 115: 38613863.

Papathanasopoulos, A. and P. Gaiannoudis (2008). Biological considerations of mesenchymal stem cells and endothelial progenitor cells. Injury International Journal of the care of the injured 39S2: S21-S32. 
Park, S., I. Kim, et al. (2006). Biological responses of ligament fibroblasts and gene expression profiling on micropatterned silicone substrates subjected to mechanical stimuli. Journal of Bioscience and Bioengineering 102(5): 402-412.

Pertigliano, F., D. McAllister, et al. (2006). Tissue engineering for anterior cruciate ligament reconstruction: A review of current strategies. Arthroscopy: The journal of Arthroscopic and related surgery 22 (4) 441-451. 22(4): 441-451.

Popp, F., E. Eggenhofer, et al. (2008). Mesenchymal stem cells can induce long-term acceptance of solid organ allografts in synergy with low-dose mycophenolate. Transplant Immunology 20: 55-69.

Portner, R., S. Bagel-Heyer, et al. (2005). Bioreactor design for tissue engineering. Journal of Bioscience and Bioengineering 100(3): 235-245.

Posthemus, M., A. September, et al. (2009). The association between the COL12A1 gene and anterior cruciate ligament ruptures. British Journal of Sports Medicine DOI: 10.1136/bjsm.2009.060756.

Probhakar, R., S. Brocchini, et al. (2005). Effect of glass composition on the degradation properties and ion release characteristics of phosphate glass-polycaprolactone composites. Biomaterials 26(15): 2209-2218.

Puk, C., D. Miller, et al. (2006). The effects of short-term stimulation on fibroblast spreading in an in vitro 3D system. Journal of Biomedical Materials Research 76A: 665-673.

Quaglia, F. (2008). Bioinspired tissue engineering: The great promise of protein delivery technologies. International Journal of Pharmaceutics.

Raif, E., B. Seedhom, et al. (2007). Cyclic Straining of cell-seeded synthetic ligament scaffolds: Development of apparatus and methodology. Tissue Engineering 13(3): 629-640.

Rathbone, S., P. Furrer, et al. (2009). Biocompatibility of polyhydroxyalkanoate as a potential material for ligament and tendon scaffold material. Journal of Biomedical Materials Research Part A DOI: 10.1002/jbm.a.32641.

Rezwan, K., Q. Ghen, et al. (2006). Biodegradable and bioactive porous polymer/inorganic composite scaffolds for bone tissue engineering. Biomaterials 27(18): 3413-3431.

Rogers, W. (1983). Cells and tissues. An introduction to histology and cell biology, Academic press Inc.(London) Ltd.

Sahoo, S., H. Ouyang, et al. (2006). Characterization of a novel polymeric scaffold fro potential application in tendon/ligament tissue engineering. Tissue Engineering 12(1): 1-9.

Sakai, S., H. Masuhara, et al. (2005). Transition of mechanical property of porous alginate scaffold with cells during culture period. Journal of Bioscience and Bioengineering 100(1): 127-129.

Sakoda, S., H. Shin, et al. (1999). Mechanical stretching of human osteoblast-like cells stimulates bone morphogenic proteins and macrophage colony-stimulating factor productions. Pathophysiology 6: 63-69.

Salasznyk, R., W. Williams, et al. (2004). Adhesion to vitronectin and collagen I promotes osteogenic differentiation of human mesenchymal stem cells. Journal of Biomedicine and Biotechnology 2004(1): 24-34.

Scherping, S., C. Schmidt, et al. (1997). Effect of growth factors on the proliferation of ligament fibroblasts from skeletally mature rabbits. Connective tissue research 36(1): $1-8$. 
Schlenker, H.-J., L. Kreja, et al. (2006). Effect of mechanical strain on human tenocytes seeded on a novel polylactide scaffold for tissue engineering of ligaments. Journal of Biomechanics 39(Suppl 1): S222.

Schmidt, C., H. Georgescu, et al. (1995). Effect of growth-factors on the proliferation of fibroblast from the medial collateral and anterior cruciate ligaments. Journal of orthopaedic research 13(2): 184-190.

Schulze-Tanzil, G., A. Mobasheri, et al. (2004). Cultivation of human tenocytes in highdensity culture. Histochemistry and Cell Biology 122: 219-228.

Screen, H., J. Shelton, et al. (2005). Cyclic tensile strain upregulates collagen synthesis in isolated tendon fascicles. Biochemical and Biophysical Research Communications 336: 424-429.

Sechler, J., S. Corbett, et al. (1997). Modulatory Roles for integrin activation and the synergy site of fibronectin during Matrix assembly. Molecular biology of the cell 8: 2563-2573.

September, A., M. Schwellnus, et al. (2007). Tendon and ligament injuries: The genetic component. British Journal of Sports Medicine 41(4): 241-246.

Shishataskaya, E., T. Volova, et al. (2004). Tissue response to the implantation of biodegradable polyhydroxyalkanoate sutures. Journal of Materials Science: Materials in Medicine. 15: 719-728.

Spindler, K., A. Imro, et al. (1996). Patellar tendon and anterior cruciate ligament have different mitogenic responses to platelet-derived growth factor and transforming growth factor beta. Journal of orthopaedic research 14(4): 542-546.

Swart, J., A. Martens, et al. (2008). Mesenchymal stem cells: A future for the treatment of arthritis? Joint Bone Spine 75: 379-382.

Tabata, Y. (2003). Tissue regeneration based on growth factor release. Tissue Engineering 9(Supplement 1): S5-S15.

Teh, T., J. Goh, et al. (2008). Comparative study of random and aligned nanofibrous scaffolds for tendon/ligament tissue engineering. Journal of Biomechanics 41 (S1)(S1): S527.

Tetsunaga, T., T. Furumatsu, et al. (2009). Mechanical stretch stimulates integrin aV $\beta 3-$ mediated collagen expression in human anterior cruciate ligament cells. Journal of Biomechanics 42: 2097-2103.

Toyoda, T., H. Matsumoto, et al. (1998). Tensile load and the metabolism of anterior cruciate ligament cells. Clinical Orthopaedics and Related Research 353: 247-256.

Utukuri, M., H. Somayaji, et al. (2006). Update on paediatric anterior cruciate injuries. The knee 13(5): 345-352.

Van Eijk, F., D. Saris, et al. (2004). Tissue engineering of ligaments: A comparison of bone marrow stromal cells, anterior cruciate ligament, and skin fibroblasts as a cell source. Tissue Engineering 10(5-6): 893-903.

Vergis, A. and J. Gillquist (1995). Graft failure in Intra-Articular anterior cruciate ligament reconstructions: A review of the literature. Arthroscopy: The Journal of Arthroscopic and related surgery 11(3): 312-321.

Vohra, S., K. Hennessy, et al. (2008). Comparison of mesenchymal stem cell and osteosarcoma cell adhesion to hydroxyapatite. Journal of Material Science: Materials in Medicine 19: 3567-3574.

Vunjak-Novakovic, G., G. Altman, et al. (2004). Tissue engineering of ligaments. Annual Review of Biomedical Engineering 6: 131-156. 
Wang, B., W. Liu, et al. (2008). Engineering of extensor tendon complex by an ex vivo approach. Biomaterials 29: 2954-2961.

Wang, J. (2006). Mechanobiology of tendon. Journal of Biomechanics 39: 1563-1582.

Wang, L., R. Shelton, et al. (2003). Evaluation of sodium alginate for bone marrow cell tissue engineering. Biomaterials 24: 3475-3481.

Wang, Y., H. Kim, et al. (2006). Stem cell-based tissue engineering with silk biomaterials. Biomaterials 27(36): 6064-6082.

Webb, K., R. Hitchcock, et al. (2006). Cyclic strain increases fibroblast proliferation, matrix accumulation, and elastic modulus of fibroblast-seeded polyurethane constructs. Journal of Biomechanics 39: 1136-1144.

Woo, S., S. Abramowitch, et al. (2006). Biomechanics of knee ligaments: injury, healing and repair. Journal of Biomechanics 39(1): 1-20.

Wu, S., H. Hsu, et al. (2009). Preparation of porous 4555 Bioglass-derived glass-ceramic scaffolds by using rice husk as a porogen additive. Journal Material Science. Materials in Medicine 20(6): 1229-1236.

Yang, G., H.-J. Im, et al. (2005). Repetitive mechanical stretching modulates IL-1 $\beta$ induced COX-2, MMP-1 expression, and PGE $_{2}$ production in human patellar tendon fibroblasts. Gene 363: 166-172.

Yu, B.-Y., P.-Y. Chen, et al. (2008). The behaviours of human mesenchymal stem cells on the poly(3-hydroxybutyrate-co-3-hydroxyhexanoate) (PHBHHx) membranes. Desalination 234: 204-211.

Zantop, T., W. Patterson, et al. (2005). Anatomy of the anterior cruciate ligament. Operative techniques in Orthopaedics 15(1): 20-28.

Zhang, L., X. Wang, et al. (2004). Cyclic stretching and co-culture with fibroblasts promote the differentiation of rat mesenchymal stem cells to ligament fibroblasts. Tissue engineering 15: P63.

Zhao, K., Y. Deng, et al. (2003). Polyhydroxyalkanoate scaffolds with good mechanical properties \& biocompatibility. Biomaterials 24: 1041-1045.

Zhao, R., L. Liao, et al. (2004). Mechanisms of and perspectives on the mesenchymal stem cell in immunotherapy. Journal of Laboratory and Clinical Medicine 143(5): 284-291. 